\title{
Spatial patterns and determinants of avocado frontier dynamics in Mexico
}

\author{
Diana Ramírez-Mejía ${ }^{1,2,3} \cdot$ Christian Levers $^{3,4} \cdot$ Jean-François Mas ${ }^{2}$
}

Received: 26 June 2021 / Accepted: 17 January 2022 / Published online: 1 March 2022

(c) The Author(s), under exclusive licence to Springer-Verlag GmbH Germany, part of Springer Nature 2022

\begin{abstract}
The surging demand for commodity crops has led to rapid and severe agricultural frontier expansion globally and has put producing regions increasingly under pressure. However, knowledge about spatial patterns of agricultural frontier dynamics, their leading spatial determinants, and socio-ecological trade-offs is often lacking, hindering contextualized decision making towards more sustainable food systems. Here, we used inventory data to map frontier dynamics of avocado production, a cash crop of increasing importance in global diets, for Michoacán, Mexico, before and after the implementation of the North American Free Trade Agreement (NAFTA). We compiled a set of environmental, accessibility and social variables and identified the leading determinants of avocado frontier expansion and their interactions using extreme gradient boosting. We predicted potential expansion patterns and assessed their impacts on areas important for biodiversity conservation. Avocado frontiers expanded more than tenfold from 12,909 ha (1974) to 152,493 ha (2011), particularly after NAFTA. Annual precipitation, distance to settlements, and land tenure were key factors explaining avocado expansion. Under favorable climatic and accessibility conditions, most avocado expansion occurred on private lands. Contrary, under suboptimal conditions, most avocado expansion occurred on communal lands. Large areas suitable for further avocado expansion overlapped with priority sites for restoration, highlighting an imminent conflict between conservation and economic revenues. This is the first analysis of avocado frontier dynamics and their spatial determinants across a major production region and our results provide entry points to implement government-based strategies to support small-scale farmers, mostly those on communal lands, while trying to minimize the socio-environmental impacts of avocado production.
\end{abstract}

Keywords Agricultural expansion · Globalization $\cdot$ Commodity frontiers $\cdot$ NAFTA $\cdot$ Extreme gradient boosting

\section{Introduction}

Communicated by Jasper Van Vliet.

Diana Ramírez-Mejía

dramirez@pmip.unam.mx

1 Posgrado en Geografía, Circuito de Posgrados SN, Universidad Nacional Autónoma de México (UNAM), Ciudad Universitaria, 04510 Coyoacán, Ciudad de México, Mexico

2 Centro de Investigaciones en Geografía Ambiental, Universidad Nacional Autónoma de México (CIGA-UNAM), Antigua carretera a Pátzcuaro, 58190 Morelia, Michoacán, Mexico

3 Institute for Resources, Environment and Sustainability, University of British Columbia, V6T 1Z4 Vancouver, BC, Canada

4 Department of Environmental Geography, Institute for Environmental Studies, Vrije Universiteit Amsterdam, 1081 HV Amsterdam, The Netherlands
Food production and crop yields have been increasing globally for the last century, driven by the expansion and intensification of agricultural land (Foley et al., 2011). An accelerated expansion and intensification of agriculture for food production is expected in the future, following demands of an increasing population and changing consumption patterns (Crist et al., 2017; Pfister et al., 2011). Current agricultural production is a major driver of biodiversity loss due to land clearing, excessive water consumption, soil erosion, overuse of pesticides and fertilizers, and related air, soil, and water pollution (Geiger et al., 2010; Ren et al., 2018; Zabel et al., 2019). Also, climate change is expected to affect water supply for crop systems, increasing the pressure on natural ecosystems for food production (Ayala et al., 2016; Elliott et al., 2014). 
The globalization of food systems has resulted in increased distances between production and consumption regions, making it difficult to establish linkages between food demand in any given place, and its environmental impacts along the supply chain (Lambin and Meyfroidt, 2011). Importing regions often export their environmental footprint to regions of agricultural production, encompassing land (Kastner et al., 2014; Laroche et al., 2020), water (Chen et al., 2018; Konar et al., 2011), or biodiversity (Lenzen et al., 2012).

Commodity crops produced for global export markets mainly originate from few low- and middle-income countries, such as Brazil, Indonesia, Congo, or Mexico, where agricultural frontier expansion is a major driver of land-use change (de Waroux et al., 2018; Gasparri and de Waroux, 2015; Ordway et al., 2017; Orozco-Ramirez et al., 2017). Moreover, large-scale deforestation due to the expansion of commodity crops (e.g. soybean, palm oil, cotton, or coffee) has been documented in several subtropical and tropical regions of South America, Southeast Asia, and sub-Saharan Africa (Laurance et al., 2014; Meyfroidt et al., 2013; Ordway et al., 2017). Such studies addressing frontier expansion dynamics have so far largely focused on major and widespread commodity crops and rather short time periods. Unfortunately, long-term frontier expansion dynamics of commodity crops with spatially concentrated production has been largely overlooked.

Avocados are a prime example of such overlooked cash crops. Avocado production is highly spatially concentrated with about $45 \%$ of the global production originating only in Mexico, thereof $\sim 80 \%$ in a single state (SIAP, 2019). The most commonly traded avocado is the Hass variety. In Mexico, Hass avocados were first introduced around the 1960s and the expansion of monocultures of this variety for trade in local and national markets started in the municipality of Uruapan (Michoacán, Mexico) in the mid-1970s (Orozco and Bocco, 2012). The implementation of North American Free Trade Agreement (NAFTA) in 1994 boosted the agricultural sector and opened the market for fruit and vegetable exports from Mexico (Orozco-Ramirez et al. 2017). Since then, the international market for Mexican avocados has continued to grow and avocado expansion in producing regions has increased substantially as a response (Denvir et al., 2021). Besides the USA and Canada as main importers, avocados from Mexico are also traded to Japan, France, China, the Netherlands, UK, Spain, among others (SIAP 2019).

The surging global demand for avocados has resulted in an accelerated expansion and intensification of avocado production in Mexico over the past decades. Deforestation, high levels of water consumption, and environmental pollution due to the excessive use of fertilizers and pesticides are among the major environmental impacts of this avocado boom (Atucha et al., 2013; GonzalezEsquivel et al., 2015; Gonzalez, 2020). This phenomenon also had detrimental effects on small-scale farmers and has resulted in outmigration from rural areas (OrozcoRamirez et al., 2017). Unfortunately, spatially explicit information on frontiers of avocado production, as well as knowledge about their main determinants and socioecological impacts is largely missing. Despite efforts to assess the potential spatial distribution of avocados and to identify suitable production areas using environmental factors and presence-only data in Colombia and across the Americas (Ramirez-Gil et al., 2019, 2018), no previous study has mapped avocado frontier dynamics in a spatially explicit way or assessed its leading spatial determinants for a production hotspot. Such information is key to address the social and environmental challenges posed by the increasing demands for agricultural commodities and to avoid undesirable future outcomes in such dynamic commodity frontier.

Our overarching goal was to map and understand frontier dynamics of avocado production in the state of Michoacán, Mexico, the dominant avocado producing region globally. We therefore used inventory data of avocado frontier expansion over 40 years, before and after NAFTA implementation. Subsequently, we used an optimized machine learning algorithm for gradient boosting to identify the most influential spatial determinants explaining frontier expansion patterns and assessed how their relative importance and interactions have changed over time. Finally, we predicted potential future expansion areas, which we overlaid with areas of conservation concern. Specifically, we addressed the following research questions:

1. Which are the most influential spatial determinants explaining frontier expansion patterns in Michoacán, Mexico, before and after the NAFTA agreement?

2. How have their relative importance and interactions changed over time?

3. What are the spatial patterns and environmental tradeoffs of potential future avocado frontier expansion?

\section{Materials and methods}

\section{Study area}

Avocado is a perennial crop currently cultivated in 28 out of 32 Mexican states, but only two states, Michoacán and Jalisco, account for almost 90\% of Mexico's avocado production (SIAP, 2019). However, Michoacán is notably the largest producer, accounting for $\sim 80 \%$ of the national production and $\sim 86 \%$ of the total Mexican avocado exports 
(Online Resource Text 1, Fig. 1). The avocado frontier in Michoacán, commonly known as the avocado belt, is located in the Trans-Mexican Volcanic Belt and the Balsas River Basin in central Mexico between $18^{\circ} 45^{\prime}$ and $20^{\circ} 0^{\prime} \mathrm{N}$ and $101^{\circ} 47^{\prime}$ and $103^{\circ} 13^{\prime} \mathrm{W}$ (Fig. 1). It spans across 61 municipalities, and 33 of them export the crop. Altitude across the avocado belt ranges from 1500 to $2400 \mathrm{~m}$ above sea level (masl). The climate is warm sub-humid with summer rainfall and annual mean temperatures between 10 and $24{ }^{\circ} \mathrm{C}$. Mean annual precipitation varies from 800 to $1600 \mathrm{~mm}$. Typical landforms in this region are mountain ranges, hills, valleys, and plateaus, and predominant soils are Andosols and Luvisols covering 80\% of the area.

The avocado belt in Michoacán is the largest avocado producing region in the world as it provides optimal conditions for industrial-scale production. Avocados are native to Mexico and Central America and evidence suggests that Mexico is the center of origin and diversification of the species Persea americana (Galindo-Tovar et al., 2008). There are several varieties of this species differing in size, shape, texture, color, and flavor. The composition of the fruit depends on the variety, degree of ripeness, climatic conditions, soil composition, and agricultural management practices. There is a great diversity of native avocado crops in Mexico, but only the Hass variety has been extensively cultivated and traded as the environmental and biophysical characteristics for growing this variety are ideal in the region and its fruit size, shelf-life, high yields, and year-round production are optimal for global commerce (Salazar-García et al., 2016).

Before NAFTA, Hass avocados produced in Michoacán were traded in local and national markets, and there was a very small number of exports mainly to France, Japan, Canada, and the UK (FAO, 2021). The accelerated increase in avocado exports was triggered by the implementation of NAFTA. After a series of tariffs and phytosanitary barriers enforced by the US government to prevent imports from Mexico in the early 1990s, the United States Department of Agriculture (USDA) began to lift the phytosanitary ban imposed on Mexican avocados during the period from 1997 to 2001 and opened its markets to imports from only the state of Michoacán, as no other state met the phytosanitary requirements. Since 2016, avocados from another state, Jalisco, were allowed to enter the US market. Tariff reductions from NAFTA and the end of the ban imposed by the

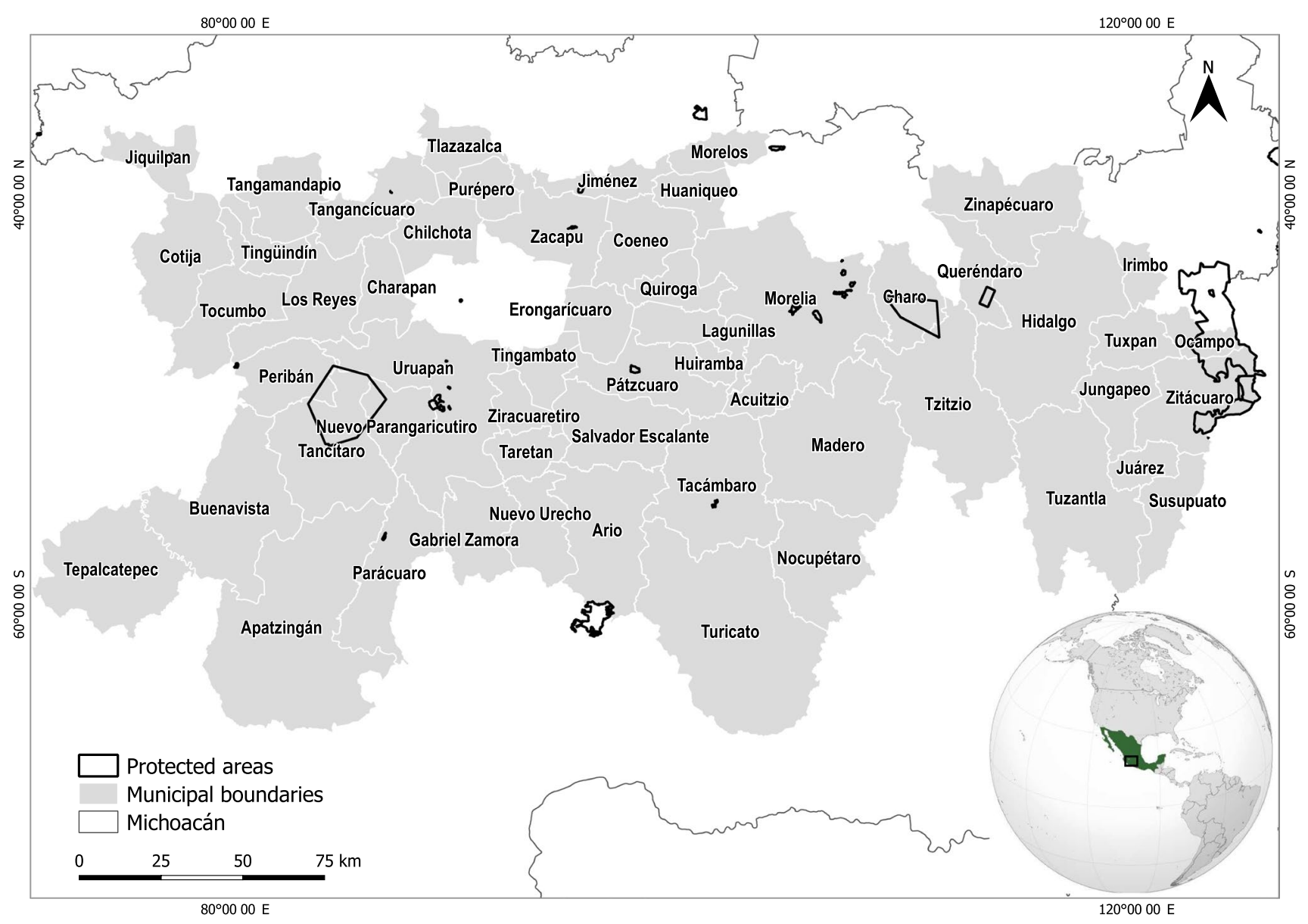

Fig. 1 Study area located in the Trans-Mexican Volcanic Belt and the Balsas River Basin in the State of Michoacán, central Mexico 
USDA favored avocado trade flow from Michoacán to the US, where consumption doubled in a 10-year period. The success of the avocado boom and its growing consumption in distant places has had severe impacts in the region, which are visible to a great extent due to the continued expansion of the avocado frontier and related socio-ecological impacts (Denvir et al., 2021).

\section{Avocado frontier inventory}

To assess the spatial determinants of avocado frontier expansion stages before and after the implementation of the NAFTA agreement, we analyzed three time periods using the avocado frontier inventory available for years 1974, 1995, and 2011 (Morales and Cuevas, 2011; Morales Manilla et al., 2012). The avocado frontier inventory expands across the Trans-Mexican Volcanic Belt and the Balsas River Basin in the State of Michoacán (Fig. 1). It was generated for the years 1974, 1995, 2007, and 2011. The inventory for the year 1974 was generated through visual interpretation of aerial photographs provided by the National Institute of Statistics and Geography (INEGI) at a scale of 1:20,000. Avocado frontier inventory data for years 1995 and 2011 was updated through visual interpretation using orthophotos at a scale of 1:20,000 from INEGI and WorldView-2 satellite images with a spatial resolution of $0.5 \mathrm{~m}$.

Considering that the first Hass avocado orchards were introduced in Michoacán around 1960, we used the period from 1960 to 1974 as our first study period, for which the latter year serves as the baseline of the avocado frontier inventory and includes all existing Hass avocado orchards until 1974 (Table 1). Our second period of analysis spans from 1974 to 1995 and represents a period during which Hass avocado monoculture expansion for local and national markets accelerated. Finally, we assessed avocado frontier expansion for the period 1995 to 2011, which coincides with the implementation of the NAFTA agreement and the further increase of avocado exports to international markets (Table 1). We used 2011 as our final year of analysis, marking the final year for which avocado frontier inventory data was available.
To match the spatial resolution of our spatial determinants (see "Spatial determinants"), we transformed the inventory maps from vector format into binary raster layers with a grid cell size of $100 \mathrm{~m}$ using nearest neighbor resampling. To generate our target variable, changes towards avocado orchards between 1974 and 1995 as well as 1995 and 2011, respectively, were labeled as expansion. Grid cells that did not change over time were labeled as no expansion.

\section{Spatial determinants}

We identified 36 potential spatial determinants related to topography, climate, soil conditions, social factors and land accessibility from literature and based on the authors' regional expertise (Online Resource Text 2). To account for collinearity among pairs of variables, we performed Spearman $\rho$ correlation analysis and removed the variable with the lower correlation to the target variable for pairs with $\rho>0.6$ (Online Resource Fig. 2). Our final set consisted of 16 spatial determinants hypothesized to explain avocado frontier expansion, which we grouped into five categories: (1) bioclimatic conditions, (2) soil conditions, (3) terrain attributes, (4) social, and (5) land accessibility (Table 2).

Bioclimatic variables were available in raster format at $\sim 90 \mathrm{~m}$ spatial resolution and terrain attributes were available at $30 \mathrm{~m}$ spatial resolution. We aggregated the respective layers to raster layers of $100 \mathrm{~m}$ spatial resolution using bilinear resampling. Soil data were available as raster layers at $\sim 250 \mathrm{~m}$ spatial resolution, which we disaggregated to raster layers of $100 \mathrm{~m}$ spatial resolution without changing original grid cell values. Land accessibility variables were available as polyline data and we transformed these layers into raster format with $100 \mathrm{~m}$ spatial resolution. We incorporated distance to settlements as a static variable due to the lack of multitemporal datasets. We calculated Euclidean distances to roads, rivers, and human settlements. Protected Areas (PA) were incorporated as a binary layer, indicating presence $(\mathrm{P})$ and absence (A) of PA. We also incorporated land tenure as a binary layer representing private $(\mathrm{Pvt})$ or communal lands (C) (Table 2). All predictor variables were projected into Lambert Conformal Conic projection (datum WGS84).

Table 1 Overview of the periods where relationships between avocado frontier expansion and environmental, land accessibility, and social spatial determinants were assessed

\begin{tabular}{lll}
\hline Period & Regime & Description \\
\hline $1960-1974$ & $\begin{array}{c}\text { Introduction } \\
\text { of } \text { Hass } \\
\text { avocado }\end{array}$ & $\begin{array}{c}\text { The period since first Hass avocado orchards were introduced in Mexico and before Hass monocultures expansion } \\
\text { begun }\end{array}$ \\
1974-1995 & $\begin{array}{l}\text { Pre-NAFTA } \\
\text { Post-NAFTA }\end{array}$ & $\begin{array}{c}\text { Avocado frontier expansion before the implementation of NAFTA, traded mostly in local and national markets } \\
\text { Avocado frontier expansion after the implementation of NAFTA, lift of USDA ban to Mexican avocado exports, } \\
\text { and rise of the avocado boom }\end{array}$ \\
\hline
\end{tabular}


Fig. 2 Spatial patterns of frontier expansion for periods 1960-1974, 1974-1995, and 1995-2011 (a) and avocado area per municipality for periods 1960-1974, 1974-1995, and 1995-2011 (b)

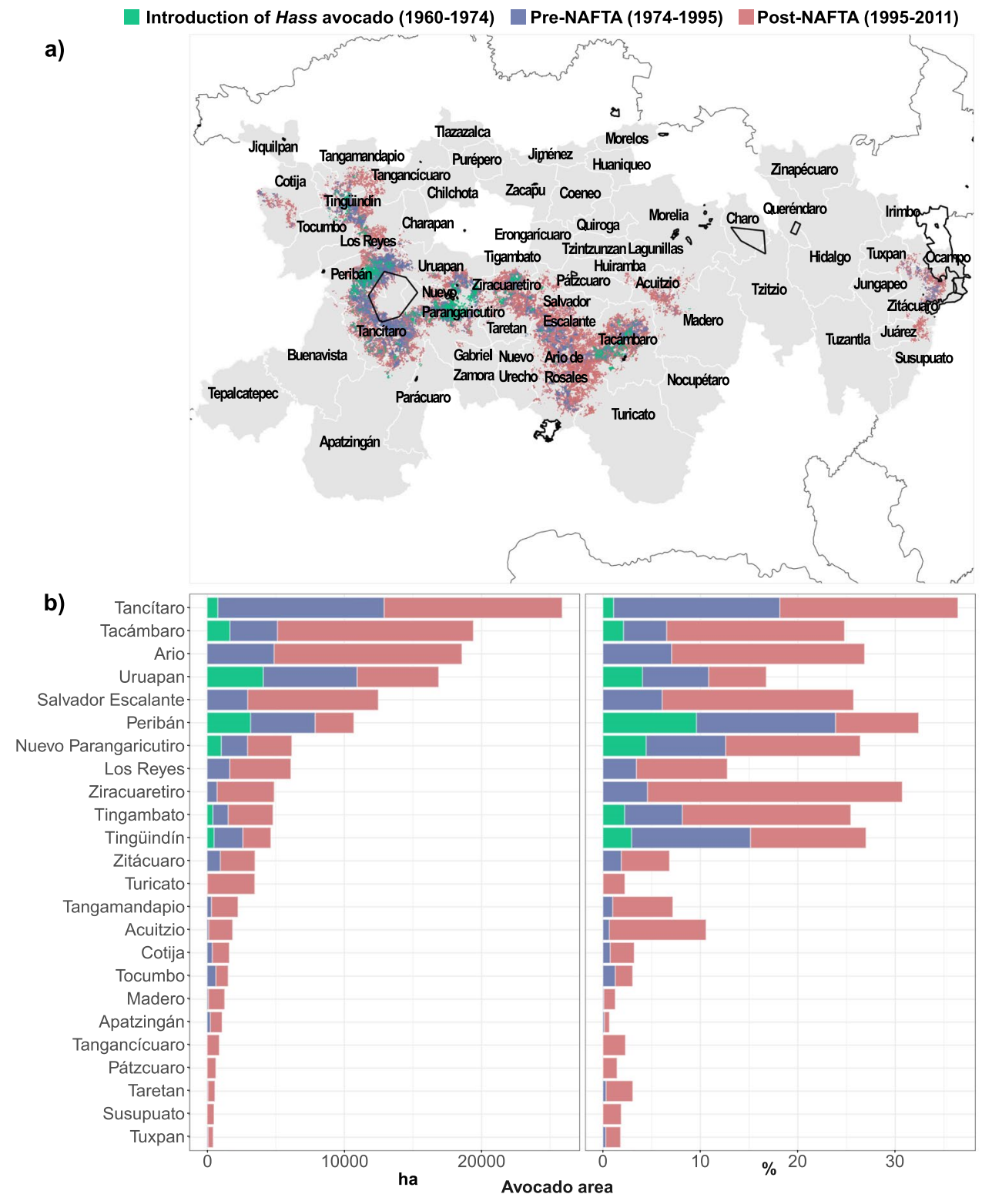

\section{Extreme gradient boosting}

We used extreme gradient boosting (XGBoost) to assess the relationships between avocado frontier expansion patterns, and their spatial determinants. XGBoost is a scalable, highly efficient, and flexible implementation of gradient boosting algorithms (detailed information in Online Resource Text 3 ) and is one of the fastest machine learning algorithms of gradient boosting (Chen and Guestrin, 2016). This algorithm incorporates multithreading and regularization to use more computational power and obtain more accurate predictions. As an extensible library, XGBoost allows users to define customized optimization objectives and evaluation metrics and incorporates features to perform cross-validation. To perform our analysis, we used the XGBoost implementation in $\mathrm{R}$ (Chen et al., 2020). XGBoost provides a wide range of parameters for model optimization and fully leveraging its predictive performance.

We used the following parameters to build our models: (1) the learning task and the corresponding learning objective (objective), determining the loss function to be used (in our case logistic regression for binary classification, returning predicted probabilities); (2) the learning rate (eta) or the step size shrinkage used to prevent overfitting; (3) the maximum depth of a tree (max_depth), controlling how deep each tree can grow during each boosting round; (4) the subsample ratio of the training instance (subsample), determining the percentage of samples used per tree; (5) the subsample ratio of columns when constructing each tree (colsample_bytree), controlling the percentage of features 
Table 2 Spatial determinants of avocado frontier expansion

\begin{tabular}{|c|c|c|c|c|c|c|}
\hline Group & Variable & Description & Unit & $\begin{array}{l}\text { Scale/spatial resolu- } \\
\text { tion }\end{array}$ & Period/year & Source \\
\hline \multirow[t]{5}{*}{ Climatic conditions } & $\begin{array}{l}\text { Annual mean tem- } \\
\text { perature }\end{array}$ & $\begin{array}{l}\text { Annual mean tem- } \\
\text { perature }\end{array}$ & ${ }^{\circ} \mathrm{C}$ & $\sim 90 \mathrm{~m}$ & 1910-2009 & $\begin{array}{l}\text { Cuervo-Robayo et al. } \\
2014\end{array}$ \\
\hline & Mean diurnal range & $\begin{array}{l}\text { Mean diurnal range } \\
\text { (Mean of monthly } \\
\text { (max temp-min } \\
\text { temp)) }\end{array}$ & ${ }^{\circ} \mathrm{C}$ & $\sim 90 \mathrm{~m}$ & 1910-2009 & $\begin{array}{l}\text { Cuervo-Robayo et al. } \\
2014\end{array}$ \\
\hline & Annual precipitation & Annual precipitation & $\mathrm{mm}$ & $\sim 90 \mathrm{~m}$ & 1910-2009 & $\begin{array}{l}\text { Cuervo-Robayo et al. } \\
2014\end{array}$ \\
\hline & $\begin{array}{l}\text { Precipitation of } \\
\text { warmest quarter }\end{array}$ & $\begin{array}{l}\text { Precipitation of } \\
\text { warmest quarter }\end{array}$ & $\mathrm{mm}$ & $\sim 90 \mathrm{~m}$ & 1910-2009 & $\begin{array}{l}\text { Cuervo-Robayo et al. } \\
2014\end{array}$ \\
\hline & Aridity & $\begin{array}{l}\text { Ratio of mean annual } \\
\text { precipitation and } \\
\text { mean annual } \\
\text { potential evapotran- } \\
\text { spiration }\end{array}$ & Dimensionless & $100 \mathrm{~m}$ & w/o year & $\begin{array}{l}\text { Own } \\
\text { calculation }\end{array}$ \\
\hline Terrain attributes & Slope & Slope in percentage & $\%$ & $100 \mathrm{~m}$ & $\mathrm{n} / \mathrm{a}$ & $\begin{array}{l}\text { Own calculation, } \\
\text { INEGI } 2017\end{array}$ \\
\hline \multirow[t]{4}{*}{ Land accessibility } & Distance to roads & $\begin{array}{l}\text { Euclidean distance to } \\
\text { roads }\end{array}$ & $\mathrm{m}$ & $1: 50,000$ & $\mathrm{n} / \mathrm{a}$ & $\begin{array}{l}\text { IMT 1996, INEGI } \\
\text { 2010, } \\
\text { INEGI } 2014\end{array}$ \\
\hline & Distance to rivers & $\begin{array}{l}\text { Euclidean distance to } \\
\text { rivers }\end{array}$ & $\mathrm{m}$ & $1: 50,000$ & $\mathrm{n} / \mathrm{a}$ & INEGI 2014 \\
\hline & $\begin{array}{l}\text { Presense/absense of } \\
\text { protected areas }\end{array}$ & $\begin{array}{l}\text { Polygons of natural } \\
\text { protected areas }\end{array}$ & Dimensionless & $\begin{array}{l}\text { ranges from } 1: 5000 \\
\text { to } 1: 150,000,000\end{array}$ & 1974-2011 & Conanp 2019 \\
\hline & $\begin{array}{l}\text { Distance to settle- } \\
\text { ments }\end{array}$ & $\begin{array}{l}\text { Euclidean distance to } \\
\text { settlements }\end{array}$ & $\mathrm{m}$ & $30 \mathrm{~m}$ & 2015 & HRSL-CIESIN 2016 \\
\hline Social & Land tenure & $\begin{array}{l}\text { Polygons of private or } \\
\text { communal lands }\end{array}$ & Dimensionless & $\begin{array}{l}\text { ranges from } 1: 100 \text { to } \\
1: 200,000\end{array}$ & $\mathrm{n} / \mathrm{a}$ & RAN 2019 \\
\hline \multirow[t]{5}{*}{ Soil conditions } & Type of soils & $\begin{array}{l}\text { Classes of types of } \\
\text { soil }\end{array}$ & Dimensionless & $1: 250,000$ & w/o year & INEGI 2007 \\
\hline & Bulk density & $\begin{array}{l}\text { Bulk density of the } \\
\text { fine earth fraction }\end{array}$ & $\mathrm{kg} / \mathrm{dm}^{3}$ & $250 \mathrm{~m}$ & w/o year & de Sousa et al. 2020 \\
\hline & $\begin{array}{l}\text { Cation exchange } \\
\text { capacity }\end{array}$ & $\begin{array}{l}\text { Cation exchange } \\
\text { capacity of the soil }\end{array}$ & $\mathrm{cmol}(\mathrm{c}) / \mathrm{kg}$ & $250 \mathrm{~m}$ & w/o year & de Sousa et al. 2020 \\
\hline & Sand & $\begin{array}{l}\text { Proportion of } \\
\text { sand particles } \\
(>0.05 \mathrm{~mm}) \text { in the } \\
\text { fine earth fraction }\end{array}$ & $\%$ & $250 \mathrm{~m}$ & w/o year & de Sousa et al. 2020 \\
\hline & Soil organic content & $\begin{array}{l}\text { Soil organic content } \\
\text { for } 0-30 \mathrm{~cm} \text { topsoil } \\
\text { layer }\end{array}$ & $\mathrm{kg} \mathrm{SOC} / \mathrm{m}^{2}$ & $250 \mathrm{~m}$ & $1991-2010$ & Guevara et al. 2020 \\
\hline
\end{tabular}

used per tree; (6) the minimum loss reduction required to make a further partition ( gamma), controlling node splits based on the expected reduction in the loss function after each split (Ogunleye and Wang, 2020; Su et al., 2018); (7) the maximum delta step allowed for each tree's weight estimation (max_delta_step) or the maximum step size that a leaf node can take, which is mostly used in logistic regressions using imbalanced data (Guo et al., 2018; Ogunleye and Wang, 2020; Song et al., 2016); and (8) the number of rounds for boosting (nrounds), determining how many decision trees are trained. For a detailed description of the tuning parameters, see Chen et al. (2020).

We converted our input data into a dense matrix (DMatrix) and fitted a model for each of the three study periods (1960-1974, 1974-1995, and 1995-2011) using a Bernoulli distribution. We conducted a hyper-parameter grid search to find the optimal parameter values to improve model performance (Table 3, Online Resource Table 1). We used 70\% of the data for training and the remaining $30 \%$ for validation of each model (i.e., for each study period). To account for spatial autocorrelation in our data and to remove spatial 
Table 3 Summary of final parameter values for our XGBoost models

\begin{tabular}{llllllll}
\hline & \multicolumn{7}{c}{ Hyperparameters } \\
\hline Period & Regime & eta & max_depth & subsample & colsample_bytree & gamma & max_delta_step nrounds \\
$1960-1974$ & $\begin{array}{l}\text { Introduction of Hass } \\
\text { avocado }\end{array}$ & 0.1 & 10 & 0.75 & 0.66 & 1 & 1 \\
$\begin{array}{l}1974-1995 \\
\text { Pre-NAFTA }\end{array}$ & 0.05 & 10 & 0.75 & 0.66 & 1 & 1 \\
$1995-2011$ & Post-NAFTA & 0.05 & 10 & 0.75 & 0.66 & 1 & 1 \\
\hline
\end{tabular}

sorting bias when performing cross-validation, we conducted pairwise distance sampling to our train and evaluation data. This method provides reliable model performance and prevents overfitting when using spatial machine learning approaches that do not account for spatial dependencies (Hijmans, 2012; Meyer et al., 2019). We performed tenfold cross-validation using the area under the curve (AUC) of the receiver operating characteristic (ROC) curve as evaluation metric. Additionally, we set XGBoost to randomly sample $75 \%$ of the training data during each model iteration. We applied a threshold value of 0.5 to classify the output probabilities into binary classes, where grid cells with predicted probability $\geq 0.5$ were classified as expansion and values less than 0.5 were classified as no expansion.

To assess the goodness-of-fit of our models, we calculated the following evaluation metrics for binary classifications obtained from the confusion matrix: true positive rate (proportion of correctly identified positives), true negative rate (proportion of correctly identified negatives), balanced accuracy (sum of correctly identified positives and negatives over two), precision (proportion of correctly identified positives in relation to all observed positives), and prevalence (sum of true positives and false negatives over the sample size). We used the model for the 1995-2011 period to predict the probability of avocado frontier expansion for each grid cell in our study area. We selected this model to generate our final prediction as it better depicts the avocado expansion dynamics this region will likely continue to experience in the future. To estimate the areas of potential avocado expansion, we reclassified the predicted probabilities of expansion into suitable $(\geq 0.7)$, moderate $(<0.7$ and $\geq 0.5)$, and suboptimal areas $(<0.5$ and $\geq 0.3)$.

\section{Model interpretation}

We used SHAP values, SHapley Additive exPlanations, to interpret model results (Lundberg et al., 2020; Lundberg and Lee, 2017). SHAP values provide a novel way for interpreting ensemble and deep learning models. It is based on Shapley values, a method from coalitional game theory
(Shapley, 1953). SHAP values explain the model's prediction by measuring the contribution of each observation for each variable (i.e., local explanations) and combining the local explanations to provide overall feature importance. Furthermore, SHAP values allow to capture local interaction effects and provide a consistent way of measuring hidden pairwise interaction relationships (Lundberg et al., 2020). A complete description and detailed mathematical explanation of SHAP's framework is provided by Lundberg and Lee (2017) and Lundberg et al. (2020). We visualized model results with SHAP feature importance plots, SHAP local explanations summary plots and maps, SHAP dependence plots showing the effect each feature has on the prediction of the model, and SHAP interaction effects plots using the R package SHAPforxgboost (Liu and Just, 2019) based on the implementation of SHAP in Python (Lundberg and Lee, 2017).

\section{Environmental impacts of frontier expansion}

To explore trade-offs between avocado expansion and biodiversity, we compared spatial patterns of observed and potential expansion areas inside and outside (1) priority sites for biodiversity conservation (Urquiza-Haas et al. 2009; Conabio 2016), (2) important sites for crop wild relatives' (CWR) conservation (Tobón-Niedfeldt et al., 2021), and (3) priority sites for restoration (Tobón et al. 2017) (Online Resource Table 2). Priority sites for biodiversity conservation are based on biological data and their pressure factors and represent priority sites for conservation of terrestrial vulnerable species and habitats (Conabio, 2016; Urquiza-Haas et al., 2009). Important sites for CWR conservation in Mexico represent areas of high CWR species richness and integrate information on genetic diversity, CWR tolerance to human-modified habitats, and their extinction risks (Tobón-Niedfeldt et al., 2021). Priority sites for restoration integrate criteria and indicators on vegetation types, elevation zones, soil degradation, and fragmentation and represent areas of biological importance and restoration feasibility in Mexico (Tobon et al., 2017). First, we 
calculated the sum of overlapping areas of avocado orchards in 2011 over each of the three conservation maps. Second, we reclassified the predicted probabilities of expansion into suitable $(\geq 0.7)$, moderate $(<0.7$ and $\geq 0.5)$, and suboptimal areas $(<0.5$ and $\geq 0.3)$ and calculated the sum of overlapping areas over each of the three conservation maps.

\section{Results}

\section{Spatial determinants of avocado frontier expansion}

We observed an accelerating avocado frontier expansion in Michoacán since 1974 (Fig. 2a). The extent of avocado orchards was 12,909 ha, 58,281 ha, and 152,493 ha in 1974, 1995, and 2011, respectively. Until 2011, only six municipalities accounted for $\sim 68 \%(104,285 \mathrm{ha})$ of the total avocado production. In 1974, Peribán and Uruapan had the largest extent of avocado orchards, accounting for 3,166 ha and 4,091 ha, respectively (Fig. 2b). Tancítaro had an extent of 783 ha in 1974 , but expanded its orchards to 12,899 ha in 1995 , and up to 25,879 ha in 2011 , thus becoming the largest avocado producing municipality in Michoacán (Fig. 2b).

Our models discriminated well between expansion and no expansion locations, resulting in high model fits (Table 4). Balanced accuracy and true positive rate were highest for the preNAFTA model (0.924), followed by the post-NAFTA model (0.907), and the introduction of Hass avocado model (0.889). Model precision was highest for the introduction of Hass avocado model, followed by the pre-NAFTA and post-NAFTA models.

For the introduction of Hass avocado period, the most important variables explaining avocado orchard expansion were annual precipitation, precipitation of warmest quarter, distance to roads, distance to settlements, and slope (Fig. 3a). SHAP summary plots show that the proximity to settlements and roads and high precipitation values, were positively related to the expansion of avocado orchards (Fig. 3b).

For the pre-NAFTA period, precipitation of warmest quarter, annual precipitation, distance to settlements, annual mean temperature, and land tenure were the most important variables explaining avocado frontier expansion (Fig. 3a). Likewise, for the post-NAFTA period, precipitation of warmest quarter, annual precipitation, distance to settlements, land tenure, and annual mean temperature were the most important variables explaining avocado frontier expansion (Fig. 3a). For both periods, SHAP summary plots show that high precipitation and proximity to settlements were positively related to avocado frontier expansion (Fig. 3b). Also, private lands (Pvt) were positively related to expansion, whereas in communal lands (C) associated with negative SHAP values less expansion occurred (Fig. 3b).

SHAP dependence plots showed non-linear relationships for all spatial determinants of avocado expansion (Fig. 4). In addition, the SHAP local explanation maps allowed us to visualize the spatial distribution of the SHAP values, indicating regions where determinants had positive, neutral, or negative associations to the expansion of avocado orchards. During the introduction of Hass avocado period (1960-1974), annual precipitation beyond $1300 \mathrm{~mm}$ was positively related to the presence of avocados, whereas in areas with lower precipitation, the presence of avocados was less likely (Fig. 4a). We observed the same trend for precipitation of warmest quarter, with a distinct threshold at around $400 \mathrm{~mm}$, beyond which precipitation was strongly positively related to the presence of avocado orchards. Locations within $400 \mathrm{~m}$ distance from settlements were positively related to the presence of avocado orchards (Fig. 4a). The areas with the strongest positive association between determinants and avocado orchard locations were mostly located in the central-western region of the avocado belt, mainly in the municipality of Uruapan (Fig. 4a).

The general patterns of the relationships between spatial determinants and avocado orchard locations we found in the introduction of Hass avocado period remained relatively stable in the pre- and post-NAFTA periods. We observed a decrease in avocado frontier expansion at precipitation levels greater than $500 \mathrm{~mm}$ and $1400 \mathrm{~mm}$ and a slight increase of frontier expansion in areas further away from settlements (Fig. 4b, c). Areas with the strongest positive association between determinants and avocado frontier expansion extended into the central and western region of Michoacán during the pre-NAFTA period, most notably in the western part of the avocado belt in the municipalities of Tancítaro and Peribán (Fig. 4b). In contrast, these areas shifted to the central-southern and eastern

Table 4 Goodness-of-fit measures for the predicted probability of avocado expansion

\begin{tabular}{llllllll}
\hline \multirow{2}{*}{ Period } & Evaluation metrics & & & & & & \\
\cline { 2 - 7 } & Regime & AUC & $\begin{array}{c}\text { Balanced } \\
\text { accuracy }\end{array}$ & TPR & TNR & Precision & Prevalence \\
\hline $1960-1974$ & Introduction of Hass avocado & 0.924 & 0.889 & 0.783 & 0.996 & 0.894 & 0.035 \\
$1974-1995$ & Pre-NAFTA & 0.970 & 0.924 & 0.857 & 0.990 & 0.873 & 0.073 \\
$1995-2011$ & Post-NAFTA & 0.962 & 0.907 & 0.837 & 0.976 & 0.817 & 0.110 \\
\hline
\end{tabular}

$T P R$, true positive rate; $T N R$, true negative rate 
Fig. 3 a SHAP feature importance plots of mean absolute SHAP value for periods 1960-1974 (introduction of Hass avocado), 1974-1995 (pre-NAFTA), and 1995-2011 (post-NAFTA) and b SHAP local explanation summary plots where each dot corresponds to an individual observation. Y-axis shows each feature (i.e., spatial determinant) and $x$-axis displays SHAP values for each observation of each feature. Positive or negative SHAP values indicate whether the effect of a value is associated with a higher or lower than random probability of avocado expansion. Color represents the value of each determinant from low (blue) to high (red). Overlapping dots in y-axis show the distribution of SHAP values per determinant. Land tenure: communal lands (C); private lands $(\mathrm{Pvt})$. Protected areas: presence (P); absence (A) a) Feature importance

b) Local explanation summary Introduction of Hass avocado (1960-1974)
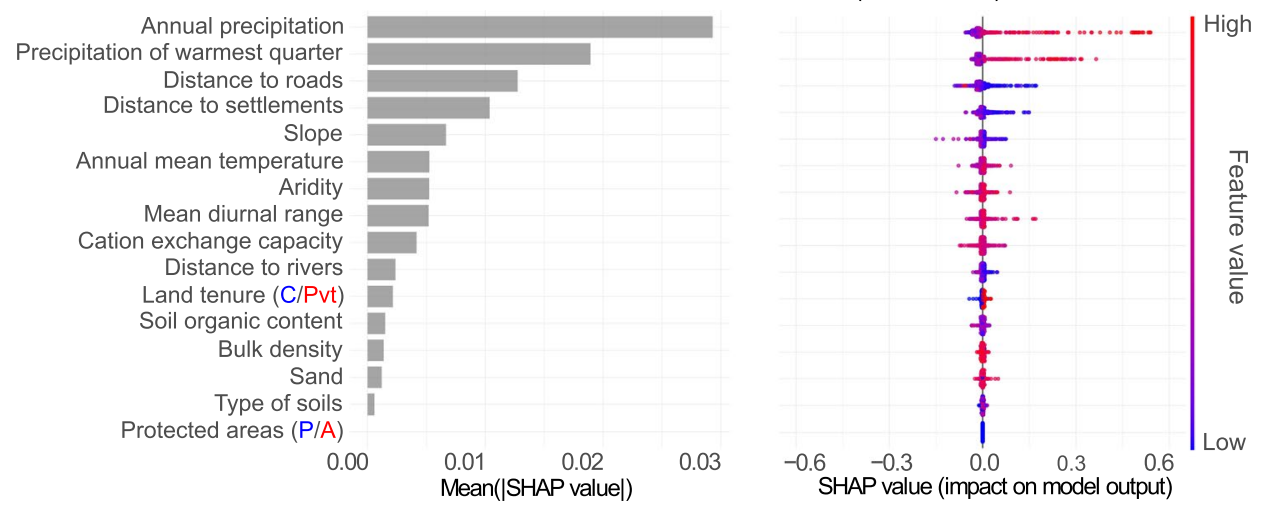

Pre-NAFTA (1974-1995)
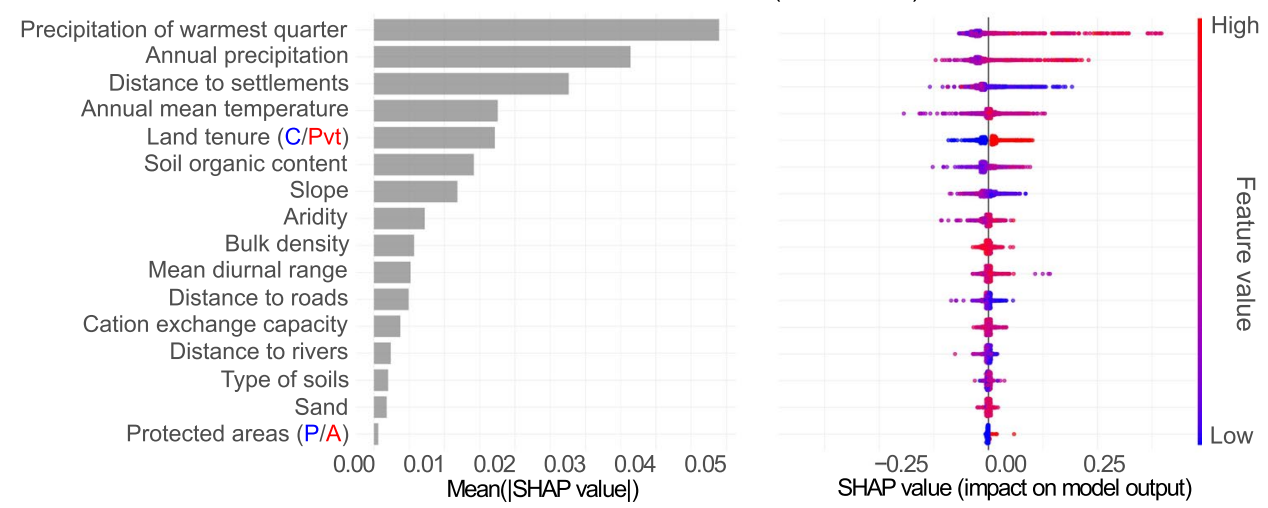

Post-NAFTA (1995-2011)
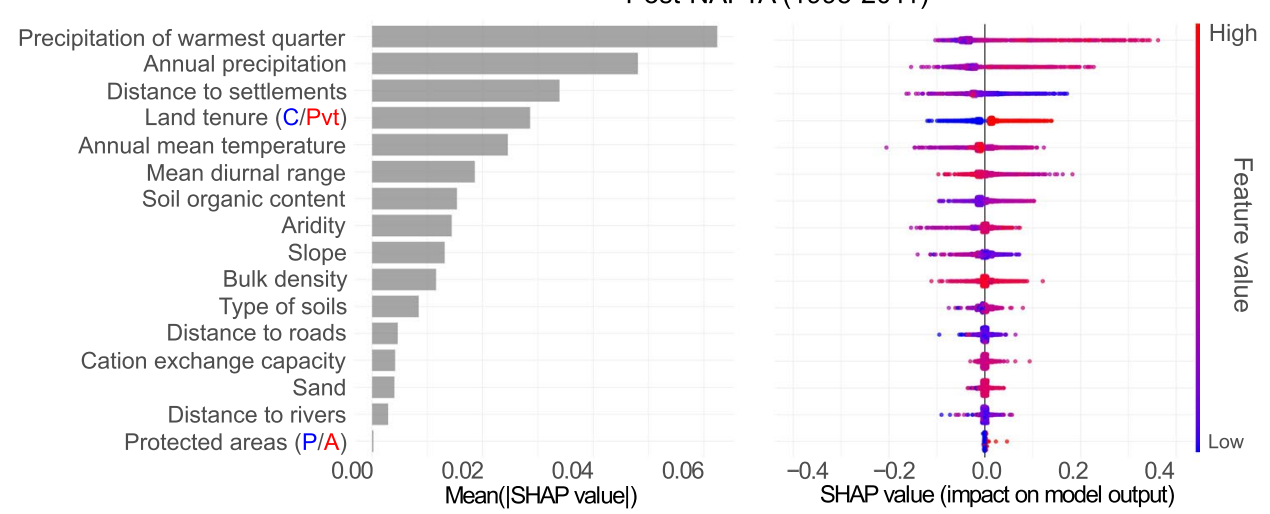

part of the avocado belt region during the post-NAFTA period, particularly into the municipalities of Salvador Escalante, Ario de Rosales, and Tacámbaro (Fig. 4c).

\section{Interaction effects of the spatial determinants of avocado frontier expansion}

During the introduction of Hass avocado period, we found major interaction effects between annual precipitation and slope, precipitation of the warmest quarter and annual mean temperature, and slope and distance to settlements (Fig. 5a). Steep slopes with high annual precipitation and annual mean temperature greater than $20^{\circ} \mathrm{C}$ were negatively related to the presence of avocado orchards. Contrary, flat areas with high annual precipitation and annual mean temperature between 15 and $20^{\circ} \mathrm{C}$ were positively related to the presence of avocado orchards (Fig. 5a).

During pre- and post-NAFTA periods, we observed interaction effects between land tenure and annual precipitation, annual mean temperature, and distance to settlements (Fig. 5b). During the pre-NAFTA period, private lands close to settlements and with high annual precipitation were positively related to avocado frontier expansion, whereas communal land areas located further away from settlements (>300 m) and with less precipitation $(<1100 \mathrm{~mm})$ showed an increased probability of avocado expansion. Furthermore, 
a) Introduction of Hass avocado (1960-1974)

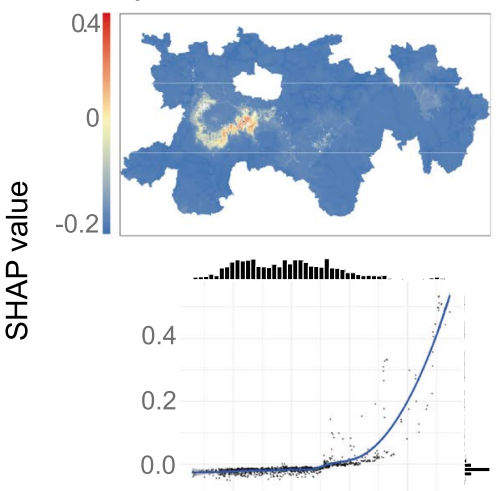

800100012001400

Annual precipitation (mm)

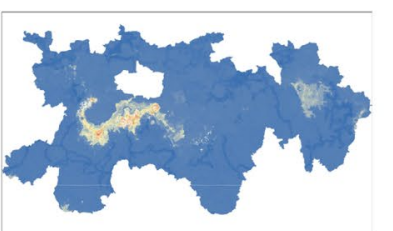

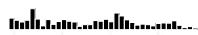

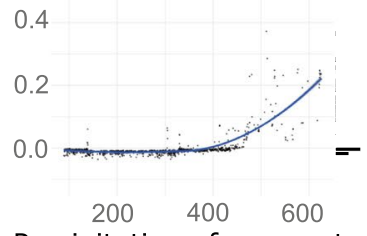

Precipitation of warmest quarter $(\mathrm{mm})$

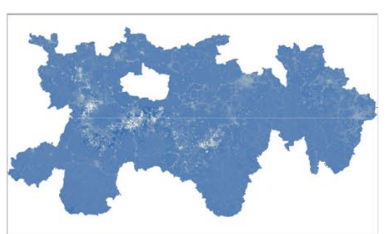

Illinumin......-.-.-.

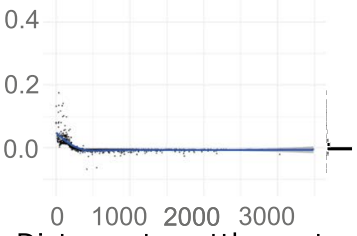

Distance to settlements (m)

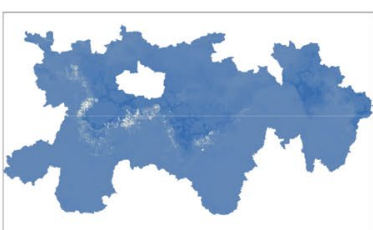

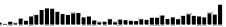

0.4

0.2

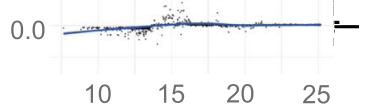

Annual mean temperature

$\left({ }^{\circ} \mathrm{C}\right)$

b) Pre-NAFTA (1974-1995)
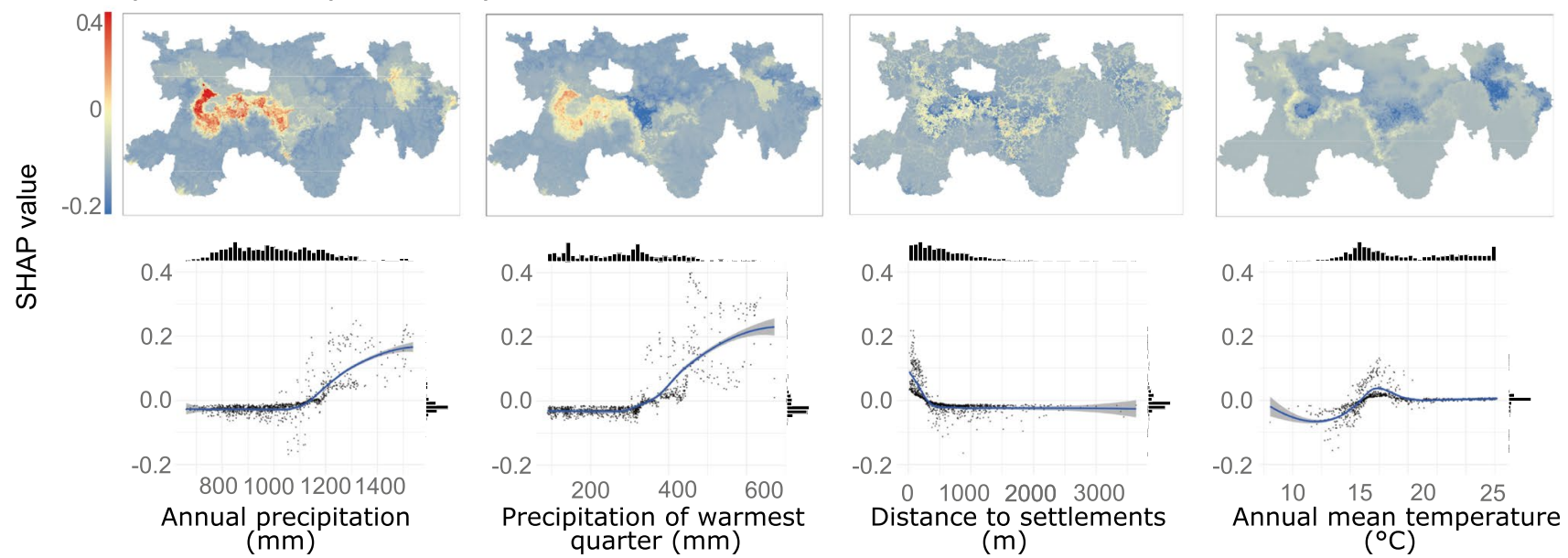
$-0.2$
$0 \quad 100020003000$
Distance to settlements

(m)

$\left({ }^{\circ} \mathrm{C}\right)$

\section{c) Post-NAFTA (1995-2011)}
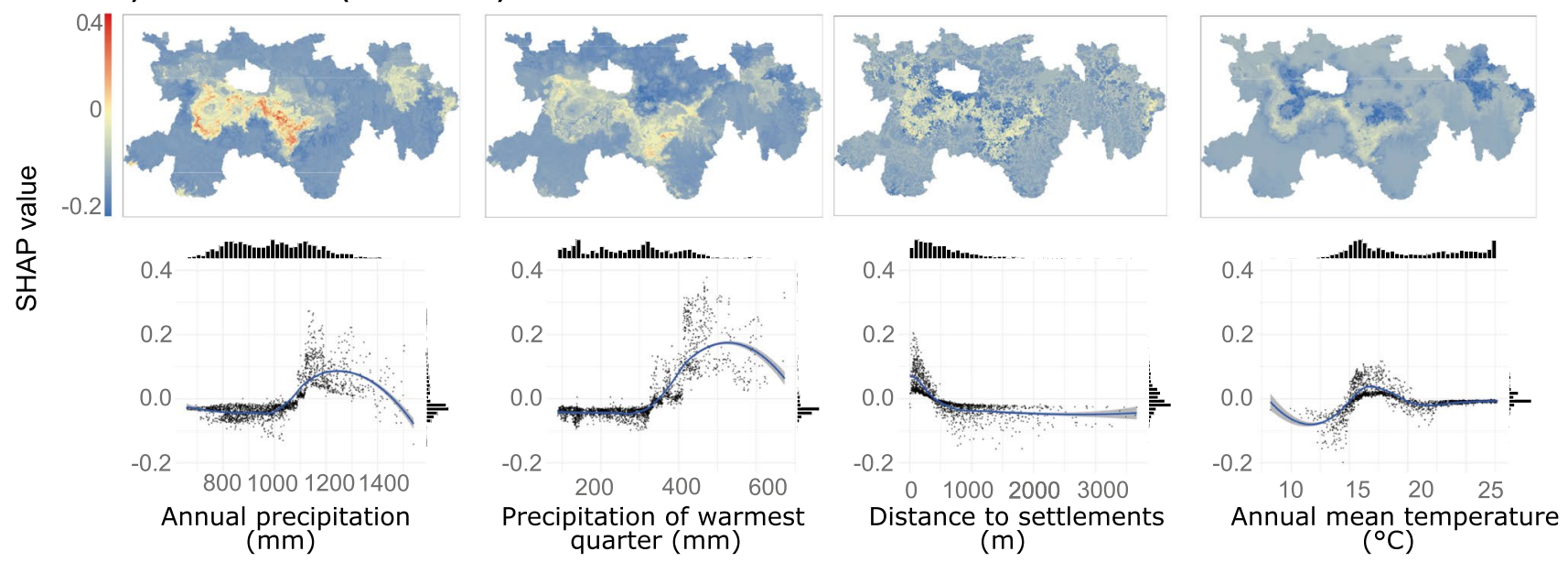

Fig. 4 SHAP dependence plots and spatial distribution of SHAP local values for the four most important variables explaining a avocado expansion during 1960-1974 (introduction of Hass avocado), b frontier expansion during 1974-1995 (pre-NAFTA), c and frontier expansion during 1995-2011 (post-NAFTA). The x-axis shows the distribution of each observation for each determinant and the y-axis shows the corresponding SHAP values. Histograms show the variable distribution along the $\mathrm{x}$ - and $\mathrm{y}$-axis 
a) Introduction of Hass avocado

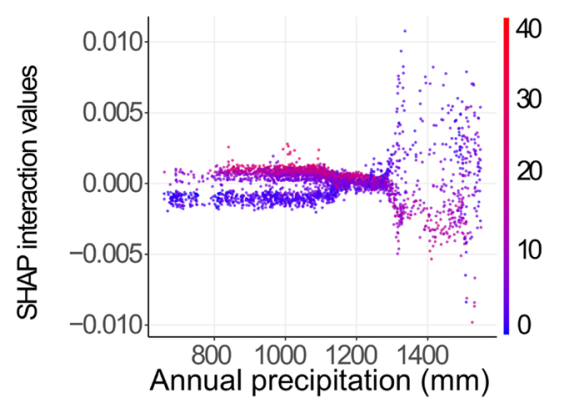

b) Pre-NAFTA

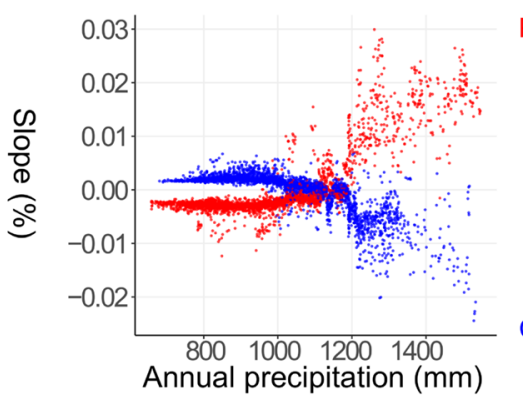

c) Post-NAFTA

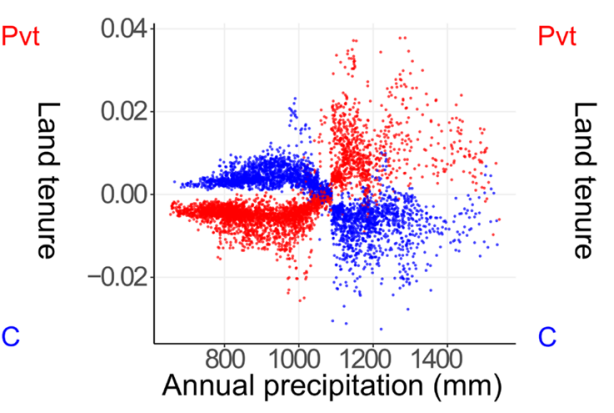

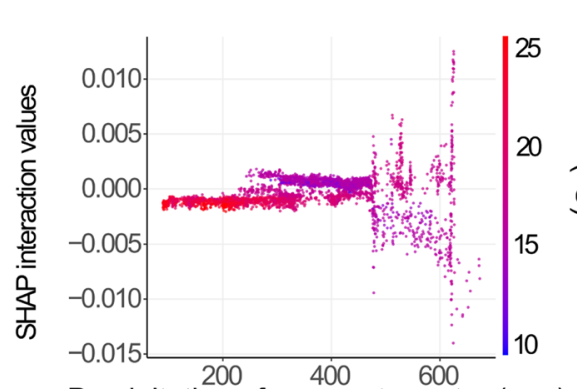

Precipitation of warmest quarter $(\mathrm{mm})$
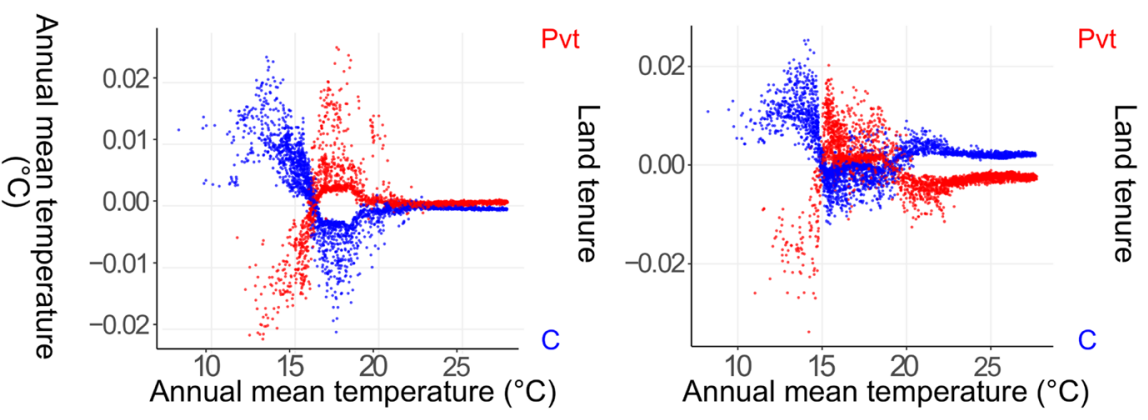

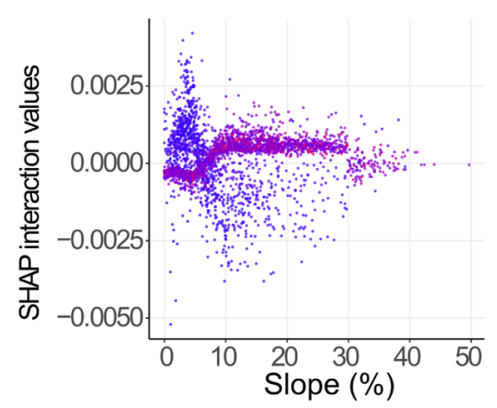

3000
2000
1000

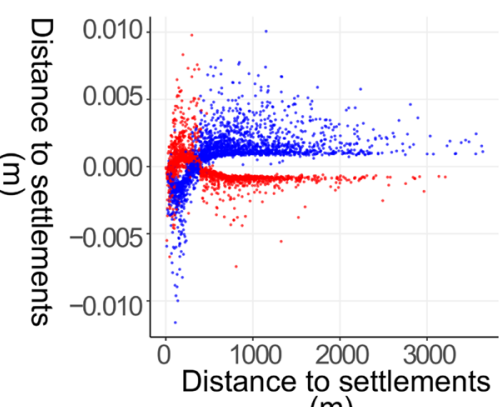

(m)

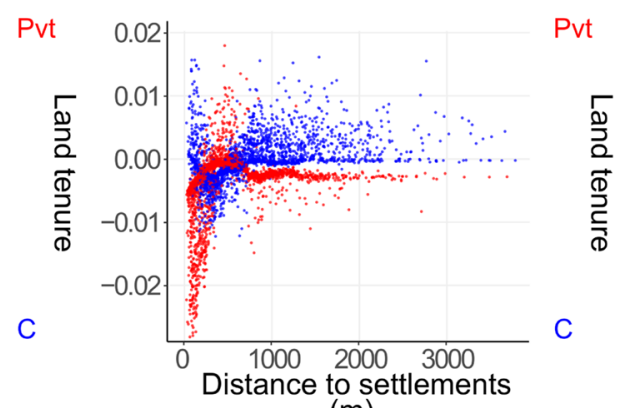

(m)
Fig. 5 SHAP dependence plots with interactions effects for a period 1960-1974 (introduction of Hass avocado), b period 1974-1995 (pre-NAFTA), and c period 1995-2011 (post-NAFTA). Positive or negative SHAP interaction values indicate if the effect of a value is associated with a higher or lower than random probability of avocado expansion. C: communal lands; Pvt: private lands avocado expansion on private lands showed strong interactions with annual mean temperature around optimal growing conditions $\left(16-20^{\circ} \mathrm{C}\right)$, while avocado expansion on communal lands was related to less suitable temperatures $\left(11-16^{\circ} \mathrm{C}\right)$.

Interaction effects during the post-NAFTA period were similar to the pre-NAFTA period. Private lands with high values of annual precipitation and optimal annual mean temperature were positively related to avocado frontier expansion. However, the probability of expansion increased in areas with less suitable temperatures and with less precipitation on communal lands (Fig. 5c). In general, interaction effects revealed that private lands were more likely to be converted to avocado orchards given optimal environmental and accessibility conditions. On the contrary, communal lands under optimal environmental and accessibility conditions remained unaltered, as shown by negative SHAP values. Moreover, communal lands under suboptimal conditions were more likely to be converted to avocado orchards than private lands under similar conditions.

\section{Prediction of potential areas for avocado frontier expansion}

Areas of high predicted probabilities for new avocado orchard expansion were mostly located adjacent to existing orchards. However, we also observed potential new emerging hotspots of avocado expansion in the eastern part of the study area and near the boundaries of the Monarch Butterfly Biosphere Reserve, located in the municipalities of Zitácuaro and Ocampo (Fig. 6).

We observed a clear trend towards the expansion of new avocado orchards into climatically suboptimal areas 


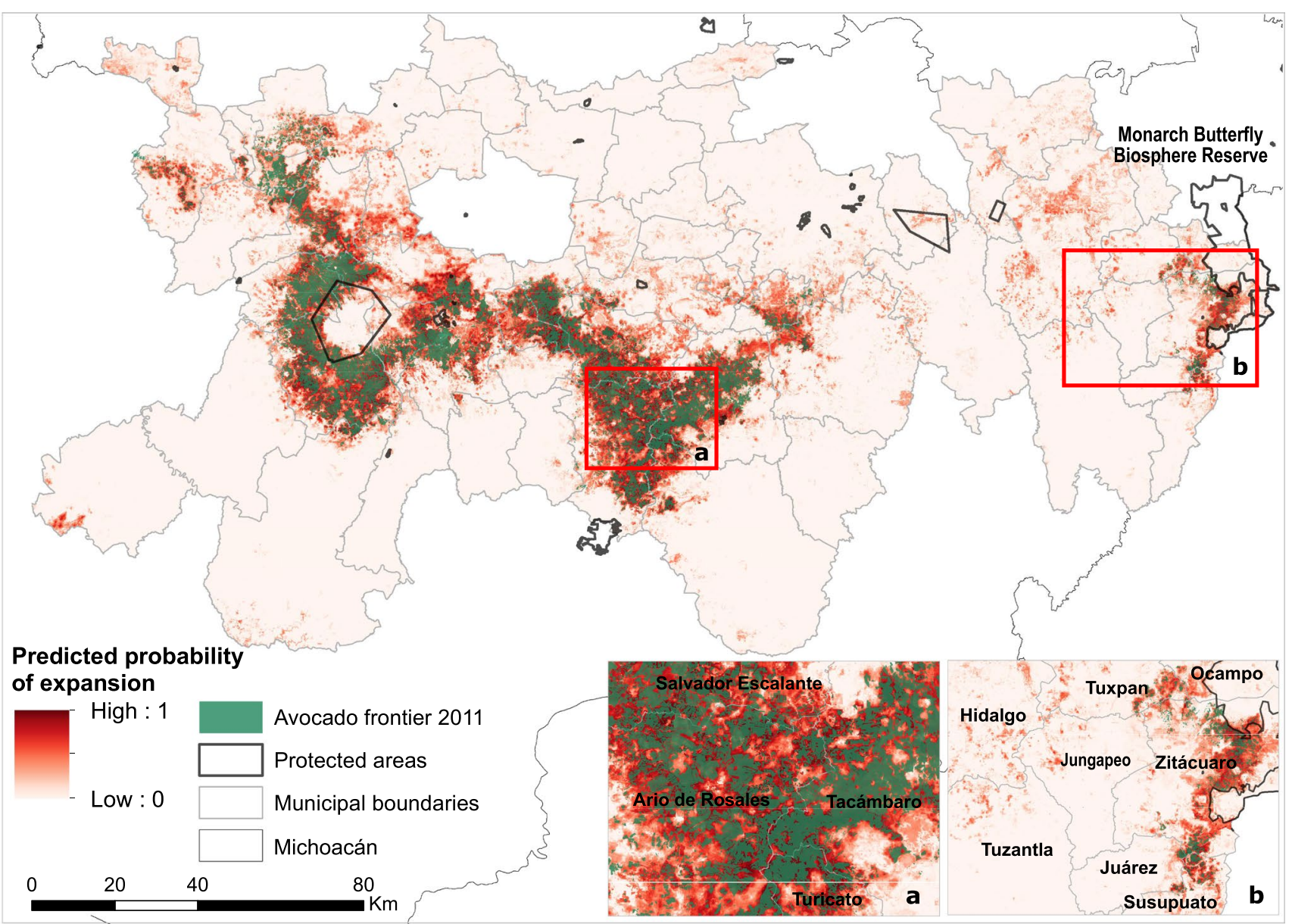

Fig. 6 Predicted probability of avocado expansion. a Predicted avocado orchards adjacent to existing orchards and b predicted avocado expansion near the boundaries of the Monarch Butterfly Biosphere Reserve and new emerging hotspots in the eastern part of the study region

in terms of annual mean temperature and annual precipitation (Fig. 7). Avocado frontier expansion areas during the pre-NAFTA period appeared further away from settlements, roads, and rivers, and on steeper slopes. This expansion into less accessible and less climatically suitable areas slightly increased during the post-NAFTA period. We observed a continuation of these trends for potential avocado expansion in suitable areas (probability threshold $\geq 0.7$ ), suggesting that future expansion areas will likely be displaced into more ecologically marginal regions.

In addition, using a probability threshold $\geq 0.7$, suitable areas for potential avocado expansion accounted for 11,827 ha. Furthermore, potential avocado expansion in moderate (threshold between $<0.7$ and $\geq 0.5$ ) and suboptimal (threshold between $<0.5$ and $\geq 0.3$ ) areas for production accounted for 27,617 ha and 62,192 ha, respectively.

Most of the observed and potential avocado frontier expansion occurred mainly outside priority sites for biodiversity conservation and important sites for crop wild relatives' conservation (Fig. 8). The contrary occurred regarding priority sites for restoration, as a larger expansion occurred inside compared to outside these sites.

\section{Discussion}

We analyzed spatial patterns of avocado frontier expansion in Michoacán, Mexico, before and after the implementation of NAFTA and assessed how the relative importance and interactions of spatial determinants explaining these patterns have changed during a 40 -year period of turbulent socioeconomic and political change in Mexico. Four major insights emerged from our analysis. First, avocado frontier expansion increased substantially across time and space, most strongly post-NAFTA. Second, the expansion of avocado orchards during 1960-1974 was mainly related to accessibility and environmental factors, i.e., annual precipitation, distance to roads, distance to settlements, and slope, whereas during pre- and post-NAFTA periods, land tenure and annual mean temperature were important factors in determining 
Fig. 7 Box plots of the main spatial determinants of avocado expansion during the introduction of Hass avocado (1960-1974), pre-NAFTA (1974-1995), and post-NAFTA (1995-2011) periods and for potential avocado expansion in suitable areas (probability threshold $\geq 0.7$ )

\section{白Introduction of Hass avocado 追 Pre-NAFTA}
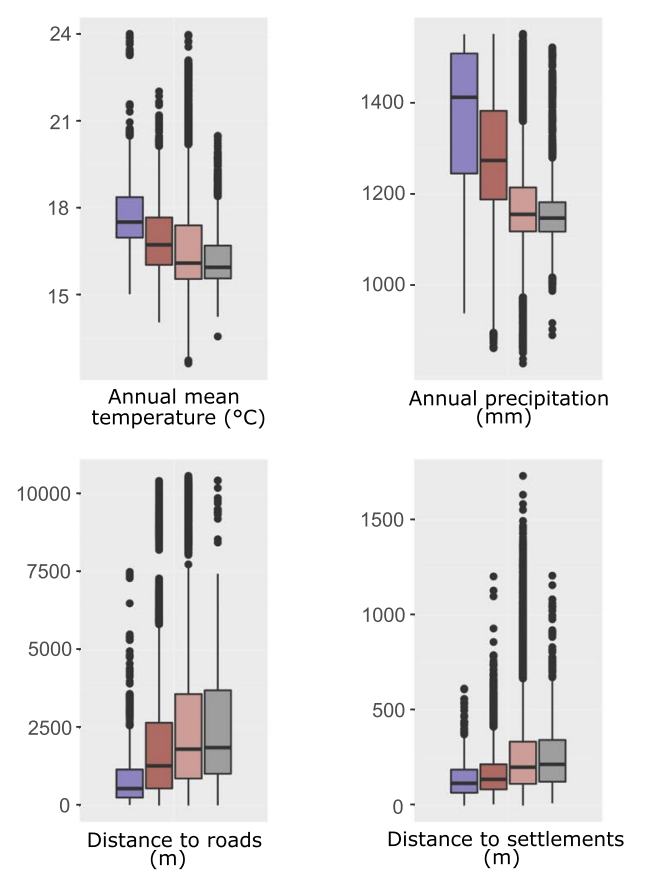

追Post-NAFTA 追 Potential expansion areas
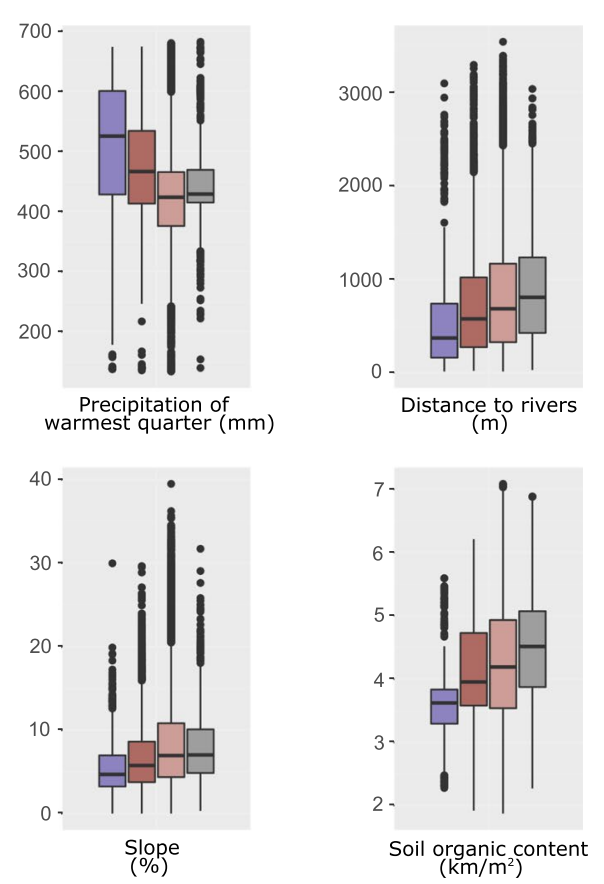
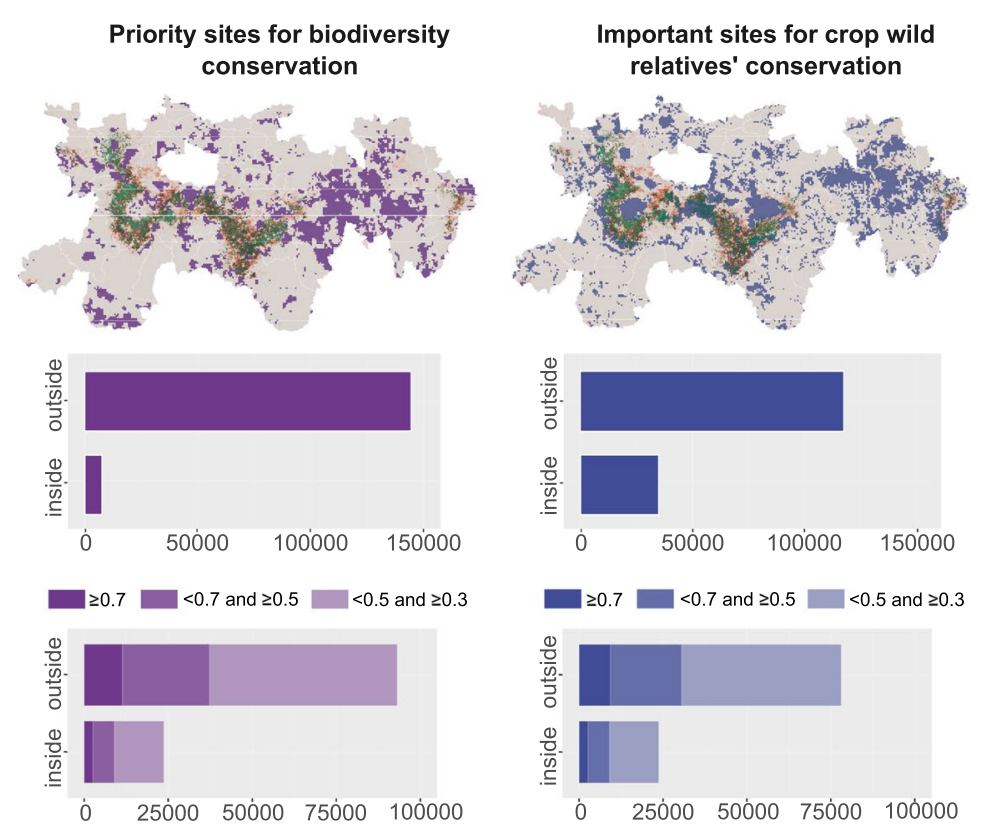
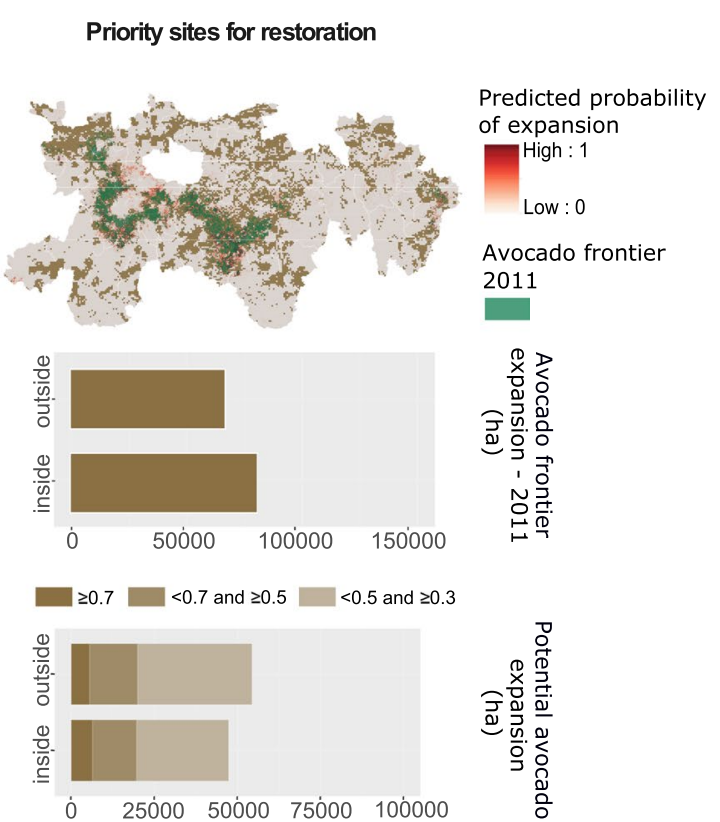

Fig. 8 Spatial patterns of observed avocado frontier expansion and potential expansion in suitable $(\geq 0.7)$, moderate $(<0.7$ and $\geq 0.5)$, and suboptimal areas $(<0.5$ and $\geq 0.3)$ inside and outside priority sites for biodiversity conservation, important sites for crop wild relatives' conservation, and priority sites for restoration

potential future avocado expansion areas will likely entail substantial environmental trade-offs, due to encroachment on important areas for crop wild relatives' conservation, as well as on areas with high biological value and feasibility for ecological restoration. Considering the increasing demands for agricultural commodities that are rapidly transforming cussions for the livelihoods of small-scale farmers. Fourth, 
the spatial patterns of land-use change in globalized production systems, our results facilitate a better understanding of frontier expansion dynamics of commodity crops.

\section{Effects of environmental conditions and accessibility on avocado frontier expansion}

Distance to settlements was the major accessibility factor determining avocado expansion across the avocado belt in Michoacán during the three periods analyzed. Several studies have linked land-use change (e.g., deforestation for agricultural expansion) to more accessible, flat areas with high road and population density (Jakovac et al., 2017; Salonen et al., 2012; Verburg et al., 2014). Although we found that better accessibility increased the probability of avocado expansion, we also observed a clear trend towards the establishment of new avocado orchards in areas farther away from settlements, roads, and rivers, and with steeper slopes during pre- and post-NAFTA periods. This suggests that avocado frontier expansion is not only driving crop substitution and displacement of traditional crop systems distributed near settlements and local markets but also indicates that avocado orchards are expanding into more distant areas, resulting in pine-oak forest clearing in the region (Bravo-Espinosa et al., 2014). Displacement of shifting cultivation and replacement of forested areas driven by export-oriented crop production are processes observed also in other world regions, especially in Southeast Asia and sub-Saharan Africa, such as Vietnam (Meyfroidt et al., 2013), Congo (Ordway et al., 2017), or Cameroon (Ordway et al., 2019). Increased frontier expansion caused by global agricultural commodity booms can further lead to the marginalization of local small-scale farmers (Levers et al., 2021), negatively affecting their livelihoods by an increased vulnerability due to reduced productive potential and higher exposure to volatile and unstable global markets (Abid et al., 2016; Meyfroidt et al., 2014).

\section{Effects of land tenure on avocado frontier expansion}

We found that avocado orchards during pre- and post-NAFTA periods expanded mostly in private lands. Moreover, private lands under optimal conditions were more likely to be converted to avocado orchards, whereas in communal lands, most avocado expansion occurred under suboptimal conditions. Lands under a communal regime are less likely to change towards avocado production, mainly because decisions over land use must be based on the consensus of the community, as opposed to private landowners that have individual agency over their land; therefore, new avocado orchards on communal lands tend to be established on areas that are less productive (i.e., suboptimal) and where there are fewer conflicts among community members. When lucrative activities are involved in communal land use planning, conflict among stakeholders is the most common outcome (Perez-Llorente et al., 2019). It has been reported that land-use changes arise when communal lands are sold to both insiders or outsiders (DiGiano et al., 2013), especially as the reform of Article 27 of the Mexican Constitution in 1992 ended government obligations to redistribute land and authorized individualization and private titling of lands, which also disarticulated the social sector and affected land systems of communal property. The few wellorganized communities in the region with strong governance have historically focused their resource management to forestry, preventing avocado expansion and land-use change in general, and thus protecting their natural resources and livelihoods (Barsimantov and Antezana, 2012; Orozco-Quintero and Davidson-Hunt, 2009).

However, for several communities throughout the avocado belt in Michoacán, avocado frontier expansion has resulted in profound land tenure regime changes, reigniting old conflicts over land titling, holding size, and land use (Barsimantov and Antezana, 2012). Moreover, post-NAFTA, economic incentives prompted by state and federal governments only favored large-scale commercial growers and agribusinesses, and small-scale farmers were increasingly left behind (Assies, 2008). The global avocado boom prompted by the implementation of NAFTA has increased and amplified the inequalities between large agribusinesses integrated into the global markets and local small-scale farmers facing land scarcity and lack of economic incentives (Orozco-Ramirez et al., 2017). This has further resulted in an increasing impoverishment of rural small-scale farmers, a disarticulation of local institutions, and has increased conflicts throughout the region (Ornelas, 2018). Such asymmetries in agency and power relations between actors were also observed in commodity frontiers in Argentina (de Waroux et al., 2018), Madagascar (Neimark et al., 2019), Laos (Junquera and Gret-Regamey, 2019; Ramcilovic-Suominen and Kotilainen, 2020), and Indonesia (Pichler, 2015), underlining the importance of land titling and land rights in global agricultural systems, which need to be considered in targeted and contextualized decision making.

\section{Socio-environmental trade-offs and future development pathways}

Our results revealed substantial socio-environmental impacts of the ongoing avocado production in Mexico, and thus support previous findings showing that avocado production in Michoacán has triggered deforestation, illegal logging, and landownership conflicts (De la Vega-Rivera and MerinoPerez, 2021; Perez-Llorente et al., 2019). We showed that new avocado orchards expanded into increasingly less suitable areas throughout the study region since 1974, and we expect that this trend will likely continue in the future. This process of marginalization can result in poverty traps 
for small-scale farmers (Barrett, 2008; Mastrangelo et al., 2019; Meyfroidt et al., 2013), increasing their vulnerability and impairing their ability to sustain their livelihoods. In addition, climate change trends modeled for the region are expected to negatively impact avocado production systems due to higher temperatures, lower precipitations, and more frequent extreme climate events (e.g., frosts and hail), further increasing the pressure on small-scale farmers (CharreMedellín et al. 2021).

Although we observed that priority sites for biodiversity conservation were not strongly affected by past avocado frontier expansion, some important sites for crop wild relatives' conservation have been and will likely be transformed into avocado orchards. Moreover, our results revealed that the avocado frontier is likely to expand into sites with high restoration feasibility, thus reducing the possibilities of maintaining and restoring the biological diversity and ecological functions of those sites. Our findings identified ongoing and future hotspots of avocado expansion that could potentially compromise the long-term preservation of the region's biodiversity. For instance, the boundaries of protected areas - although effective — are already under high pressures, as well as several priority sites for biodiversity conservation and important sites for crop wild relatives' conservation (Sanchez et al., 2019).

According to official census data, the total land devoted to avocados in 2018 was 175,014 ha, corresponding to an increase of 22,521 ha since 2011 (SIAP, 2018). Following our results, using a probability threshold of $\geq 0.7$, suitable areas for potential avocado expansion only accounted for half of this area $(11,827 \mathrm{ha})$. Yet, potential expansion in moderately suitable areas for production (threshold between $<0.7$ and $\geq 0.5$ ) accounted for 27,617 ha. This suggests that avocado expansion in the past years likely occurred in both suitable and less suitable areas. Avocado production and exports are expected to continue in the future, which will likely result in further expanding avocado frontiers providing that areas for production - even under suboptimal conditions - are still available. Yet, this scenario could change anytime. For instance, NAFTA's transition into the United States-Mexico-Canada Agreement (USMCA) in 2018 raised concerns and increased tensions among the actors involved in the avocado industry. A potential hold-up in the ratification process was initially suggested, which would have put Mexico's food export markets at risk. In the longerterm, it could also be possible that growing environmental concerns affect avocado demand on a global scale. Despite these concerns, the avocado industry has overcome several instabilities, such as the COVID-19 pandemic, underlining the strength of its supply chain and collaboration strategies (Lopez-Ridaura et al., 2021).

However, the environmental footprint of global avocado consumption patterns continues to exert serious pressures on local small-scale farmers, indigenous communities, and common property lands. A major concern is that as suitable lands for growing avocado become scarce, and the impacts on the environment are amplified, this system integrity can potentially be comprised. Moreover, these impacts can in turn be exacerbated in the future by reduced water availability, intense droughts, and higher susceptibility to pest invasions (Charre-Medellín et al. 2021; Chávez et al., 2019), by fluctuating market prices, changing consumer preferences, and by a fragile ecosystem facing a continuously more eroded genetic diversity of crops and crop wild relatives (Contreras-Toledo et al., 2018; Ford-Lloyd et al., 2011; Vincent et al., 2019).

\section{Limitations}

In this study, we assessed the spatial patterns of avocado frontier expansion before and after NAFTA implementation based on environmental, land accessibility, and social factors determining that expansion. Aside from expansion, the intensification of land management is crucial to understand commodity frontier dynamics as both processes usually occur together in regions characterized by export-oriented crop production (Barretto et al., 2013; Byerlee et al., 2014; Varkkey et al., 2018; Zabel et al., 2019). In Michoacán, the increasing market demands, and rising prices have stimulated the continued expansion of the avocado frontier during the past three decades and have promoted land-use intensification to increase avocado yields to meet market demands. As land for agricultural expansion becomes scarce, agricultural intensification is likely to increase (Barretto et al., 2013; Lambin and Meyfroidt, 2011; Zabel et al., 2019). Evaluating the spatiotemporal patterns of land-use intensification across the entire avocado belt region was beyond the scope of this analysis due to major data gaps about system inputs (e.g., capital per land area, cropping frequency) and outputs (e.g., agricultural yields, production volumes). However, including intensification patterns and change trajectories in our analysis would have allowed us to further improve the understanding of land-system changes and the underlying factors in this dynamic commodity frontier region.

Context-specific studies linking local scale processes to global international trade dynamics by means of spatially explicit models are still rare, although they could greatly improve our understanding of how telecoupled systems interact (Friis et al., 2016; Gasparri et al., 2016; Yu et al., 2013). Here, we addressed a set of important environmental, land accessibility and social factors determining avocado expansion. Yet, a clear understanding of the local underlying factors driving conflicts and land-use change dynamics throughout the avocado belt is still necessary. Our analysis could be greatly improved by incorporating economic (e.g., market prices for agricultural 
exports, export volumes, GDP growth, labor force), institutional (e.g., trade policies, domestic agricultural policies, trade tariffs changes), and other social (e.g., access to technology) drivers of avocado frontier expansion, which we could not incorporate due to data restrictions. Moreover, addressing flows, feedbacks, spillovers, and trade-offs along the avocado supply chain in a spatially explicit way and linking those processes to local landuse changes would offer an exciting opportunity to accurately quantify the environmental footprint of avocado production and to track the value chain from production to consumption (da Silva et al., 2021). Such approaches fall beyond the scope of the present study.

In this study, we assessed avocado frontier expansion for three periods using the avocado frontier inventory available for years 1974, 1995, and 2011. Yet, avocado production in Mexico and demand from elsewhere has continued to increase since then (Cho et al., 2021; Denvir et al., 2021). One key step towards more reliably assessing the impacts and trade-offs the avocado industry has left on this major production region is to generate an updated wall-to-wall version of the avocado inventory. This would allow validating the potential expansion areas predicted by our model against the actual avocado orchards currently found in Michoacán and in adjacent states such as Jalisco, a new and rising production hotspot. It would further allow for re-assessing the importance of spatial determinants explaining expansion patterns. Also, mapping settlement expansion since 1960 would allow to better capture settlement expansion dynamics, to refine our models' predictions, and to deepen our understanding of how this spatial determinant has influenced avocado expansion.

Finally, by using XGBoost and SHAP values, we were able to better understand the interaction effects between land tenure and environmental and accessibility variables, which thus allowed us to gain a unique insight into some underlaying processes of this expanding frontier in central Mexico. As future research, it would be useful to integrate and compare the present results with other modeling approaches based on cellular automata (Soares et al., 2006) or other land allocation models that allow incorporating dynamic variables (Verburg et al., 2013).

\section{Implications}

Landscape configuration reflects historical effects of landuse changes prompted by public policies. Avocado frontier expansion took place in a context of land policy and land tenure reforms in Mexico, but also as part of a wider context of agricultural development and trade policies (Assies, 2008). As such, the avocado industry has been shaped by contextspecific circumstances and has been mediated by national and global external forces. Our results further foster and support the discussion about the need for improving the representation of small-scale farmers in policies, regulations, and governance, and for strengthening communal land rights.

First, policies oriented towards increasing the integration of small-scale farmers into the agricultural sector are highly needed, as well as the design and implementation of strategies and incentives aimed at supporting small-scale farmers producing subsistence and domestic-oriented crops. Second, as avocado production is highly spatially concentrated, and communal lands are a key component for maintaining natural areas and avoiding conversion to avocado orchards, efforts to minimize the socio-ecological impacts of the international trade of avocado should focus on the reinforcement of communal land rights and local governance (Barsimantov and Antezana, 2012; Denvir et al., 2021). Such actions could improve the situation for the environment and small-scale farmers and could help to sustainably manage and protect biodiversity-rich areas currently at risk by expanding avocado frontiers (Sanchez et al., 2019). Third, government policy schemes could tax the environmental footprint of land converted to avocado orchards, potentially benefiting small-scale farmers already using degraded lands, over large ones clearing large areas of forests in regions with suitable environmental conditions. Fourth, the identification and mapping of supply chain actors and connections is crucial to accurately assess the environmental and social risks embedded in the production, consumption, and trade of agricultural commodities (Godar et al., 2016). Efforts to promote avocado supply-chain transparency and sustainability should focus on improving conventional regulatory frameworks and governance through multi-stakeholder initiatives (Cho et al., 2021).

Finally, fair and more equitable sharing of benefits arising from agricultural trade commodities, particularly among small-scale farmers, is essential to move towards more sustainable, efficient, and inclusive telecoupled food systems.

\section{Conclusion}

Our study provides the first spatially explicit assessment of avocado frontier expansion dynamics and how the relative importance and interactions of a set of environmental, accessibility and social factors explaining its expansion have changed between 1974 and 2011, comprising the entire period of the global avocado boom. Our study showed that spatial patterns of avocado frontier expansion reflected the historical effects of land-use changes prompted by public policies and our model's predictions revealed that new potential expansion areas will likely shift into ecologically more marginal regions. Our methodological approach highlighted the potential of machine learning algorithms and new interpretability methods (e.g., SHAP values) for broadening 
our understanding of complex socio-ecological systems. Our analysis can assist in better informing local small-scale farmers, producers, and stakeholders about the potential environmental and social costs of current production practices. Policies regulating land property rights and promoting the integration of local small-scale farmers into the agricultural sector and global markets can help to ensure more effective and equitable production systems and to improve sustainability and governance of agricultural supply chains.

Supplementary Information The online version contains supplementary material available at https://doi.org/10.1007/s10113-022-01883-6.

Acknowledgements DR-M is a doctoral student from the Programa de Doctorado en Geografía, Universidad Nacional Autónoma de México (UNAM). DR-M acknowledges N Ramankutty for hosting her as a visiting research student at the University of British Columbia. CL gratefully acknowledges support by the European Union's Horizon 2020 research and innovation programme under the Marie Skłodowska-Curie Grant Agreement No 796451 (FFSize). We are grateful to two anonymous reviewers for their thoughtful and very constructive comments that helped to improve this manuscript. The research reported in this article contributes to the Global Land Programme (http://GLP.earth).

\section{References}

Abid M, Schilling J, Scheffran J, Zulfiqar F (2016) Climate change vulnerability, adaptation and risk perceptions at farm level in Punjab, Pakistan. Sci Total Environ 547:447-460. https://doi.org/10. 1016/j.scitotenv.2015.11.125

Assies W (2008) Land tenure and tenure regimes in Mexico: an overview. J Agrar Change 8:33-63. https://doi.org/10.1111/j.14710366.2007.00162.x

Atucha A, Merwin IA, Brown MG, Gardiazabal F, Mena F et al (2013) Soil erosion, runoff and nutrient losses in an avocado (Persea americana Mill) hillside orchard under different groundcover management systems. Plant Soil 368:393-406. https://doi.org/ 10.1007/s11104-012-1520-0

Ayala LM, van Eupen M, Zhang GP, Perez-Soba M, Martorano LG et al (2016) Impact of agricultural expansion on water footprint in the Amazon under climate change scenarios. Sci Total Environ 569:1159-1173. https://doi.org/10.1016/j.scitotenv.2016.06.191

Barrett CB (2008) Poverty traps and resource dynamics in smallholder agrarian systems. Economics of Poverty, Environment and Natural-Resource Use

Barretto AGOP, Berndes G, Sparovek G, Wirsenius S (2013) Agricultural intensification in Brazil and its effects on land-use patterns: an analysis of the 1975-2006 period. Global Change Biol 19:1804-1815. https://doi.org/10.1111/gcb.12174

Barsimantov J, Antezana JN (2012) Forest cover change and land tenure change in Mexico's avocado region: is community forestry related to reduced deforestation for high value crops? Appl Geogr 32:844-853. https://doi.org/10.1016/j.apgeog.2011.09.001

Bravo-Espinosa M, Mendoza ME, Allende TC, Medina L, Saenz-Reyes JT et al (2014) Effects of converting forest to avocado orchards on topsoil properties in the Trans-Mexican Volcanic System, Mexico. Land Degrad Dev 25:452-467. https://doi.org/10.1002/ldr.2163

Byerlee D, Stevenson J, Villoria N (2014) Does intensification slow crop land expansion or encourage deforestation? Glob Food Secur-Agr 3:92-98. https://doi.org/10.1016/j.gfs.2014.04.001
Conabio (2016) Sitios de atención prioritaria para la conservación de la biodiversidad, escala: 1:1 000 000. Comisión Nacional para el Conocimiento y Uso de la Biodiversidad. México.

Contreras-Toledo AR, Cortes-Cruz MA, Costich D, Rico-Arce MD, Brehm JM et al (2018) A crop wild relative inventory for Mexico. Crop Sci 58:1292-1305. https://doi.org/10.2135/cropsci2017.07. 0452

Crist E, Mora C, Engelman R (2017) The interaction of human population, food production, and biodiversity protection. Science 356:260-264. https://doi.org/10.1126/science.aal2011

Cuervo-Robayo AP, Tellez-Valdes O, Gomez-Albores MA, VenegasBarrera CS, Manjarrez J et al (2014) An update of high-resolution monthly climate surfaces for Mexico. Int J Climatol 34:24272437. https://doi.org/10.1002/joc.3848

Charre-Medellín J, Mas J, Chang-Martínez L (2021) Potential expansion of Hass avocado cultivation under climate change scenarios threatens Mexican mountain ecosystems. In Press Crop and Pasture Science 72:291-301. https://doi.org/10.1071/CP20458

Chávez AGT, Morales-Chávez R, García-González Y, Francisco A, Rojas GT (2019) Partición de la precipitación en cultivo de aguacate y bosque de pino-encino en Michoacán, México. Biológicas 21:1-18

Chen B, Hanb MY, Peng K, Zhou SL, Shao L et al (2018) Global landwater nexus: agricultural land and freshwater use embodied in worldwide supply chains. Sci Total Environ 613:931-943. https:// doi.org/10.1016/j.scitotenv.2017.09.138

Chen TQ, Guestrin C (2016) XGBoost: A scalable tree boosting system. Kdd'16: Proceedings of the 22nd Acm Sigkdd International Conference on Knowledge Discovery and Data Mining:785-794. doi:https://doi.org/10.1145/2939672.2939785

Chen TQ, He T, Benesty M, Khotilovich V, Tang Y et al (2020) xgboost: extreme gradient boosting. $\mathrm{R}$ package version 1.0.0.2. https://CRAN.R-project.org/package =xgboost.

Cho KM, Goldstein B, Gounaridis D, Newell JP (2021) Where does your guacamole come from? Detecting deforestation associated with the export of avocados from Mexico to the United States. J Environ Manage 278. https://doi.org/10.1016/j.jenvman.2020.111482

da Silva RFB, Vina A, Moran EF, Dou Y, Batistella M et al (2021) Socioeconomic and environmental effects of soybean production in metacoupled systems. Sci Rep-Uk 11. https://doi.org/10.1038/ S41598-021-98256-6

De la Vega-Rivera A, Merino-Perez L (2021) Socio-environmental impacts of the avocado boom in the Meseta Purepecha, Michoacan, Mexico. Sustainability-Basel 13.

de Sousa LM, Poggio L, Batjes NH, Heuvelink GBM, Kempen B et al (2020) SoilGrids 2.0: producing quality-assessed soil information for the globe. Soil Discuss 1. https://doi.org/10.5194/soil-2020-65

de Waroux YL, Baumann M, Gasparri NI, Gavier-Pizarro G, Godar J et al (2018) Rents, actors, and the expansion of commodity frontiers in the Gran Chaco. Ann Am Assoc Geogr 108:204-225. https://doi.org/10.1080/24694452.2017.1360761

Denvir A, Arima EY, Gonzalez-Rodriguez A, Young KR (2021) Ecological and human dimensions of avocado expansion in Mexico: towards supply-chain sustainability. Ambio. https://doi.org/10. 1007/s13280-021-01538-6

DiGiano M, Ellis E, Keys E (2013) Changing landscapes for forest commons: linking land tenure with forest cover change following Mexico's 1992 agrarian counter-reforms. Hum Ecol 41:707723. https://doi.org/10.1007/s10745-013-9581-0

Elliott J, Deryng D, Mueller C, Frieler K, Konzmann M et al (2014) Constraints and potentials of future irrigation water availability on agricultural production under climate change. P Natl Acad Sci USA 111:3239-3244. https://doi.org/10.1073/pnas.1222474110

Facebook Connectivity Lab and Center for International Earth Science Information Network - CIESIN - Columbia University (2016) High Resolution Settlement Layer (HRSL). Source 
imagery for HRSL (c) 2016 DigitalGlobe. Available online: https://ciesin.columbia.edu/data/hrsl/

FAO, 2020. FAOSTAT Statistical Database. http://faostat.fao.org/.

Foley JA, Ramankutty N, Brauman KA, Cassidy ES, Gerber JS et al (2011) Solutions for a cultivated planet. Nature 478:337-342. https://doi.org/10.1038/nature10452

Ford-Lloyd BV, Schmidt M, Armstrong SJ, Barazani O, Engels J et al (2011) Crop wild relatives-undervalued, underutilized and under threat? Bioscience 61:559-565. https://doi.org/10.1525/ bio.2011.61.7.10

Friis C, Nielsen JO, Otero I, Haberl H, Niewohner J et al (2016) From teleconnection to telecoupling: taking stock of an emerging framework in land system science. J Land Use Sci 11:131153. https://doi.org/10.1080/1747423X.2015.1096423

Galindo-Tovar ME, Ogata-Aguilar N, Arzate-Fernandez AM (2008) Some aspects of avocado (Persea americana Mill.) diversity and domestication in Mesoamerica. Genet Resour Crop Ev 55:441450. https://doi.org/10.1007/s10722-007-9250-5

Orozco CG, Bocco G (2012) Cambios de uso del suelo en la meseta purépecha (1976-2005). Instituto Nacional de Ecología.

Gasparri NI, de Waroux YL (2015) The coupling of South American soybean and cattle production frontiers: new challenges for conservation policy and land change science. Conserv Lett 8:290-298. https://doi.org/10.1111/conl.12121

Gasparri NI, Kuemmerle T, Meyfroidt P, de Waroux YL, Kreft H (2016) The emerging soybean production frontier in Southern Africa: conservation challenges and the role of south-south telecouplings. Conserv Lett 9:21-31. https://doi.org/10.1111/conl.12173

Geiger F, Bengtsson J, Berendse F, Weisser WW, Emmerson M et al (2010) Persistent negative effects of pesticides on biodiversity and biological control potential on European farmland. Basic Appl Ecol 11:97-105. https://doi.org/10.1016/j.baae.2009.12.001

Godar J, Suavet C ,Gardner TA, Dawkins E, Meyfroidt P (2016) Balancing detail and scale in assessing transparency to improve the governance of agricultural commodity supply chains. Environ Res Lett 11. https://doi.org/10.1088/1748-9326/11/3/035015

Gonzalez-Esquivel CE, Gavito ME, Astier M, Cadena-Salgado M, del-Val E et al (2015) Ecosystem service trade-offs, perceived drivers, and sustainability in contrasting agroecosystems in central Mexico. Ecol Soc 20. https://doi.org/10.5751/ Es-06875-200138

Gonzalez H (2020) What socioenvironmental impacts did 35 years of export agriculture have in Mexico? (1980-2014): A transnational agri-food field analysis. J Agrar Change 20:163-187. https://doi.org/10.1111/joac.12343

Guevara M, Arroyo C, Brunsell N, Cruz CO, Domke G et al (2020) Soil organic carbon across Mexico and the conterminous United States (1991-2010) Global Biogeochem Cy 34. https://doi.org/ 10.1029/2019GB006219

Guo J, Nomura A, Barton R, Zhang HY, Matsuoka S (2018) Machine learning predictions for underestimation of job runtime on HPC system. Lect Notes Comput Sc 10776:179-198. https://doi.org/ 10.1007/978-3-319-69953-0_11

Hijmans RJ (2012) Cross-validation of species distribution models: removing spatial sorting bias and calibration with a null model. Ecology 93:679-688. https://doi.org/10.1890/11-0826.1

IMT (1996) Vías de comunicación. Instituto Mexicano del Transporte Mexico. México.

INEGI (2007) Conjunto de Datos Vectorial Edafológico. Escala 1:250 000 Serie II Continuo Nacional Instituto Nacional de Estadística y Geografía, Aguascalientes.

INEGI (2010) Red Hidrográfica escala 1:50 000 - Cuencas edición 2.0 Instituto Nacional de Estadística y Geografía, Aguascalientes.

INEGI (2014) Red Nacional de Caminos (RNC) Instituto Nacional de Estadística y Geografía, Aguascalientes.
INEGI (2017) Continuo de Elevaciones Mexicano 3.0 (CEM 3.0). Instituto Nacional de Estadística y Geografía, Aguascalientes.

Jakovac CC, Dutrieux LP, Siti L, Pena-Claros M, Bongers F (2017) Spatial and temporal dynamics of shifting cultivation in the middle-Amazonas river: expansion and intensification. Plos One 12. https://doi.org/10.1371/journal.pone.0181092

Junquera V, Gret-Regamey A (2019) Crop booms at the forest frontier: triggers, reinforcing dynamics, and the diffusion of knowledge and norms. Global Environ Chang 57. https://doi.org/10.1016/j. gloenvcha.2019.101929

Kastner T, Erb KH, Haberl H (2014) Rapid growth in agricultural trade: effects on global area efficiency and the role of management. Environ Res Lett 9. https://doi.org/10.1088/1748-9326/9/3/034015

Konar M, Dalin C, Suweis S, Hanasaki N, Rinaldo A et al (2011) Water for food: the global virtual water trade network. Water Resour Res 47. https://doi.org/10.1029/2010wr010307

Lambin EF, Meyfroidt P (2011) Global land use change, economic globalization, and the looming land scarcity. P Natl Acad Sci USA 108:3465-3472. https://doi.org/10.1073/pnas.1100480108

Laroche PCSJ, Schulp CJE, Kastner T, Verburg PH (2020) Telecoupled environmental impacts of current and alternative Western diets. Global Environ Chang 62. https://doi.org/10.1016/j.gloen vcha.2020.102066

Laurance WF, Sayer J, Cassman KG (2014) Agricultural expansion and its impacts on tropical nature. Trends Ecol Evol 29:107-116. https://doi.org/10.1016/j.tree.2013.12.001

Lenzen M, Moran D, Kanemoto K, Foran B, Lobefaro L et al (2012) International trade drives biodiversity threats in developing nations. Nature 486:109-112. https://doi.org/10.1038/nature11145

Levers C, Romero-Munoz A, Baumann M, De Marzo T, Fernandez PD et al (2021) Agricultural expansion and the ecological marginalization of forest-dependent people. Proc Natl Acad Sci U S A 118. https://doi.org/10.1073/pnas.2100436118

Liu Y, Just A (2019) SHAPforxgboost: SHAP plots for 'XGBoost'.

Lopez-Ridaura S, Sanders A, Barba-Escoto L, Wiegel J, MayorgaCortes $\mathrm{M}$ et al (2021) Immediate impact of COVID-19 pandemic on farming systems in Central America and Mexico. Agr Syst 192. https://doi.org/10.1016/J.Agsy.2021.103178

Lundberg SM, Erion G, Chen H, DeGrave A, Prutkin JM et al (2020) From local explanations to global understanding with explainable AI for trees. Nat Mach Intell 2:56-67. https://doi.org/10.1038/ s42256-019-0138-9

Lundberg SM, Lee SI (2017) A unified approach to interpreting model predictions. Adv Neur In 30.

Mastrangelo ME, Sun ZL, Seghezzo L, Muller D (2019) Survey-based modeling of land-use intensity in agricultural frontiers of the Argentine dry Chaco. Land Use Policy 88. https://doi.org/10. 1016/j.landusepol.2019.104183

Meyer H, Reudenbach C, Wollauer S, Nauss T (2019) Importance of spatial predictor variable selection in machine learning applications - moving from data reproduction to spatial prediction. Ecol Model 411. https://doi.org/10.1016/j.ecolmodel.2019.108815

Meyfroidt P, Carlson KM, Fagan ME, Gutierrez-Velez VH, Macedo MN et al (2014) Multiple pathways of commodity crop expansion in tropical forest landscapes. Environ Res Lett 9. https://doi.org/ 10.1088/1748-9326/9/7/074012

Meyfroidt P, Phuong VT, Anh HV (2013) Trajectories of deforestation, coffee expansion and displacement of shifting cultivation in the Central Highlands of Vietnam. Global Environ Chang 23:11871198. https://doi.org/10.1016/j.gloenvcha.2013.04.005

Morales LM, Cuevas G (2011) Inventarios 1974-2007 y evaluación del impacto ambiental regional del cultivo del aguacate en el estado de Michoacán. Informe Ejecutivo. Centro de Investigaciones en Geografía Ambiental, UNAM. Morelia, Michoacán

Morales LM, Cuevas G (2012) Inventario 2011 del cultivo del aguacate y evaluación del impacto ambiental forestal en el estado de 
Michoacán. Informe Ejecutivo. Centro de Investigaciones en Geografía Ambiental, UNAM. Morelia, Michoacán

Neimark B, Osterhoudt S, Alter H, Gradinar A (2019) A new sustainability model for measuring changes in power and access in global commodity chains: through a smallholder lens. Palgr Commun 5. https://doi.org/10.1057/S41599-018-0199-0

Ogunleye A, Wang QG (2020) XGBoost model for chronic kidney disease diagnosis. Ieee Acm T Comput Bi 17:2131-2140. https:// doi.org/10.1109/Tcbb.2019.2911071

Ordway EM, Asner GP, Lambin EF (2017) Deforestation risk due to commodity crop expansion in sub-Saharan Africa. Environ Res Lett 12. https://doi.org/10.1088/1748-9326/Aa6509

Ordway EM, Naylor RL, Nkongho RN, Lambin EF (2019) Oil palm expansion and deforestation in Southwest Cameroon associated with proliferation of informal mills. Nat Commun 10. https://doi. org/10.1038/s41467-018-07915-2

Ornelas RG (2018) Organized crime in Michoacan: rent-seeking activities in the avocado export market. Politics Policy 46:759-789. https://doi.org/10.1111/polp.12270

Orozco-Quintero A, Davidson-Hunt I (2009) Community-based enterprises and the commons: the case of San Juan Nuevo Parangaricutiro, Mexico. International Journal of the Commons 4. https://doi.org/10.18352/ijc.138

Orozco-Ramirez Q, Astier M, Barrasa S (2017) Agricultural land use change after NAFTA in Central West Mexico. Land-Basel 6. https://doi.org/10.3390/Land6040066

Perez-Llorente I, Ramirez MI, Paneque-Galvez J, Orozco CG, Gonzalez-Lopez R (2019) Unraveling complex relations between forest-cover change and conflicts through spatial and relational analyses. Ecol Soc 24. https://doi.org/10.5751/ Es-10992-240303

Pfister S, Bayer P, Koehler A, Hellweg S (2011) Projected water consumption in future global agriculture: scenarios and related impacts. Sci Total Environ 409:4206-4216. https://doi.org/10. 1016/j.scitotenv.2011.07.019

Pichler M (2015) Legal dispossession: state strategies and selectivities in the expansion of Indonesian palm oil and agrofuel production. Dev Change 46:508-533. https://doi.org/10.1111/dech.12162

Ramcilovic-Suominen S, Kotilainen J (2020) Power relations in community resilience and politics of shifting cultivation in Laos. Forest Policy Econ 115. https://doi.org/10.1016/J.Forpol.2020. 102159

Ramirez-Gil JG, Cobos ME, Jimenez-Garcia D, Morales-Osorio JG, Peterson AT (2019) Current and potential future distributions of Hass avocados in the face of climate change across the Americas. Crop Pasture Sci 70:694-708. https://doi.org/10.1071/CP19094

Ramirez-Gil JG, Morales JG, Peterson AT (2018) Potential geography and productivity of "Hass" avocado crops in Colombia estimated by ecological niche modeling. Sci Hortic-Amsterdam 237:287295. https://doi.org/10.1016/j.scienta.2018.04.021

RAN (2019) Perimetrales de los núcleos agrarios certificados. Registro Agrario Nacional. México.

Ren DD, Yang YH, Yang YM, Richards K, Zhou XY (2018) Landwater-food nexus and indications of crop adjustment for water shortage solution. Sci Total Environ 626:11-21. https://doi.org/ 10.1016/j.scitotenv.2018.01.071

Salazar-García S, Medina-Carrillo RE, Álvarez-Bravo A (2016) Evaluación inicial de algunos aspectos de calidad del fruto de aguacate 'Hass' producido en tres regiones de México. Revista Mexicana De Ciencias Agrícolas 7:277-289

Salonen M, Toivonen T, Cohalan JM, Coomes OT (2012) Critical distances: comparing measures of spatial accessibility in the riverine landscapes of Peruvian Amazonia. Appl Geogr 32:501-513. https://doi.org/10.1016/j.apgeog.2011.06.017
Sanchez AM, Delgado P, Gonzalez-Rodriguez A, Gonzalez C, Rojas AFGT et al (2019) Spatio-temporal approach for identification of critical conservation areas: a case study with two pine species from a threatened temperate forest in Mexico. Biodivers Conserv 28:1863-1883. https://doi.org/10.1007/s10531-019-01767-y

Shapley LS (1953) A value for n-person games. Contributions to the Theory of Games 2:307-317

SIAP (2018) Cierre de la producción agrícola por cultivo - Aguacate. Servicio de Información Agroalimentaria y Pesquera. México.

SIAP (2019) Panorama Agroalimentario 2019. Servicio de Información Agroalimentaria y Pesquera, Ciudad de México, México.

Soares BS, Nepstad DC, Curran LM, Cerqueira GC, Garcia RA et al (2006) Modelling conservation in the Amazon basin. Nature 440:520-523. https://doi.org/10.1038/nature04389

Song RW, Chen SD, Deng BL, Li L (2016) eXtreme gradient boosting for identifying individual users across different digital devices. Web-Age Information Management, Pt I 9658:43-54. https://doi. org/10.1007/978-3-319-39937-9_4

Su PH, Liu YH, Song X (2018) Research on intrusion detection method based on improved smote and XGBoost. Iccns 2018: Proceedings of the 8th International Conference on Communication and Network Security:37-41. doi:https://doi.org/10.1145/3290480. 3290505

Tobón-Niedfeldt W, Mastretta-Yanes A, Urquiza-Haas T, Goettsch B, Cuervo-Robayo A et al (2021) Incorporating evolutionary and threat processes into crop wild relatives conservation. bioRxiv. https://doi.org/10.1101/2021.06.15.448560

Tobon W, Urquiza-Haas T, Koleff P, Schroter M, Ortega-Alvarez $\mathrm{R}$ et al (2017) Restoration planning to guide Aichi targets in a megadiverse country. Conserv Biol 31:1086-1097. https://doi.org/ 10.1111/cobi.12918

Urquiza-Haas T, Kolb M, Koleff P, Lira-Noriega A, Alarcón J (2009) Methodological approach to identify Mexico's terrestrial priority sites for conservation. The Gap Analysis Program in Brief 61:60

Varkkey H, Tyson A, Choiruzzad SA (2018) Palm oil intensification and expansion in Indonesia and Malaysia: environmental and socio-political factors influencing policy. Forest Policy Econ 92:148-159. https://doi.org/10.1016/j.forpol.2018.05.002

Verburg PH, Tabeau A, Hatna E (2013) Assessing spatial uncertainties of land allocation using a scenario approach and sensitivity analysis: a study for land use in Europe. J Environ Manage 127:S132-S144. https://doi.org/10.1016/j.jenvman.2012.08.038

Verburg R, Rodrigues S, Lindoso D, Debortoli N, Litre G et al (2014) The impact of commodity price and conservation policy scenarios on deforestation and agricultural land use in a frontier area within the Amazon. Land Use Policy 37:14-26. https://doi.org/10.1016/j. landusepol.2012.10.003

Vincent H, Amri A, Castaneda-Alvarez NP, Dempewolf H, Dulloo E et al (2019) Modeling of crop wild relative species identifies areas globally for in situ conservation. Commun Biol 2. https://doi.org/ 10.1038/S42003-019-0372-Z

Yu Y, Feng KS, Hubacek K (2013) Tele-connecting local consumption to global land use. Global Environ Chang 23:1178-1186. https:// doi.org/10.1016/j.gloenvcha.2013.04.006

Zabel F, Delzeit R, Schneider JM, Seppelt R, Mauser W et al (2019) Global impacts of future cropland expansion and intensification on agricultural markets and biodiversity. Nat Commun 10. https:// doi.org/10.1038/S41467-019-10775-Z

Publisher's Note Springer Nature remains neutral with regard to jurisdictional claims in published maps and institutional affiliations. 